\title{
Recent Developments in Nanotechnology for Detection and Control of Aedes aegypti-Borne Diseases
}

\author{
Estefânia Vangelie Ramos Campos ${ }^{1}$, Jhones Luiz de Oliveira ${ }^{2}$, \\ Daniele Carvalho Abrantes ${ }^{2}$, Carolina Barbára Rogério ${ }^{2}$, Carolina Bueno ${ }^{2}$, \\ Vanessa Regina Miranda ${ }^{2}$, Renata Aparecida Monteiro ${ }^{2}$ and \\ Leonardo Fernandes Fraceto ${ }^{2 *}$
}

${ }^{1}$ Human and Natural Sciences Center, Federal University of ABC, Santo André, Brazil, ${ }^{2}$ São Paulo State University - UNESP, Institute of Science and Technology, Sorocaba, Brazil

OPEN ACCESS

Edited by:

Eden Morales-Narváez, Centro de Investigaciones en

Optica, Mexico

Reviewed by: Abdelrahim H. A. Hassan, Beni-Suef University, Egypt

Jie Liu,

South China Agricultural University, China

${ }^{*}$ Correspondence: Leonardo Fernandes Fraceto leonardo.fraceto@unesp.br

Specialty section: This article was submitted to

Nanobiotechnology,

a section of the journal Frontiers in Bioengineering and

Biotechnology

Received: 27 November 2019 Accepted: 03 February 2020

Published: 20 February 2020

Citation:

Campos EVR, de Oliveira JL, Abrantes DC, Rogério CB, Bueno C

Miranda VR, Monteiro RA and

Fraceto LF (2020) Recent

Developments in Nanotechnology for Detection and Control of Aedes

aegypti-Borne Diseases.

Front. Bioeng. Biotechnol. 8:102. doi: 10.3389/fbioe.2020.00102
Arboviruses such as yellow fever, dengue, chikungunya and zika are transmitted mainly by the mosquito vector Aedes aegypti. Especially in the tropics, inefficacy of mosquito control causes arboviruses outbreaks every year, affecting the general population with debilitating effects in infected individuals. Several strategies have been tried to control the proliferation of $A$. aegypti using physical, biological, and chemical control measures. Other methods are currently under research and development, amongst which the use of nanotechnology has attracted a lot of attention of the researchers in relation to the production of more effective repellents and larvicides with less toxicity, and development of rapid sensors for the detection of virus infections. In this review, the utilization of nano-based formulations on control and diagnosis of mosquito-borne diseases were discussed. We also emphasizes the need for future research for broad commercialization of nano-based formulations in world market aiming a positive impact on public health.

Keywords: Aedes aegypti, vector control, biosensors, larvicides, arboviruses, nanobiotechnology

\section{INTRODUCTION}

Rampant growth of human population has led to major challenges of sustainable food production and disease control in the twenty-first century (Roni et al., 2015). Arthropods are vectors of some deadly diseases, which can lead to epidemics or pandemics (Murugan et al., 2015). On top of the list are mosquitoes (Diptera: Culicidae) that are a cause of a major concern around the world because they can act as vectors of a variety of harmful pathogens and parasites (Benelli, 2016; Benelli and Mehlhorn, 2016). Aedes aegypti and Aedes albopictus are the most important global vectors of arboviruses, such as dengue, yellow fever, chikungunya, and zika viruses (Durán et al., 2016). Arboviruses have long been treated as neglected diseases around the world. However, in recent years there have been a number of epidemics caused by arboviruses - such as dengue, chikungunya, yellow fever and unprecedented zika (Wilder-Smith et al., 2017). The main factors contributing to these outbreaks have been considered to be urbanization, modernization and increased international mobility of the general population (Tavares et al., 2018).

Control of arboviruses is difficult due to many factors, such as lack of effective vaccines for most of the arboviruses, lack of antiviral drugs, insecticide resistance in the vectors such as Aedes species 
and failure of vector control strategies that would decrease human-vector contact (Batool et al., 2018). In this scenario, development of new approaches to rapidly detect, and control dissemination of arboviruses are a priority and a public health imperative. In this regard, the importance of nanobiotechnology has been gradually realized as an emerging technology of the future due to exceptional new benefits (Suganya et al., 2017). In the vector control applications, nanoparticles could be applied for: (a) the development of new drugs, with higher activity, decreased toxicity and sustained release; (b) development of new repellent formulations based on natural or synthetic compounds; (c) control of vectors by the use of nanoparticles with repellent, insecticidal or larvicidal activities (Magro et al., 2019); and (d) development of biosensors that can rapidly detect and diagnose the mosquito transmitted viral diseases (Durán et al., 2016; Benelli et al., 2017; Nicolini et al., 2017a). Due to the lack of specific drugs for viral diseases, nanobiotechnology has appeared as an important new breakthrough, which could be potentially used for treatment of patients infected with arboviruses. VivaGel ${ }^{\circledR}$ is a poly-L-lysine dendrimer-based formulation, which has shown efficient antiviral activity against zika virus (ZIKV) (Starpharma, 2016). Recently, a number of reviews have been published on the contribution of nanotechnology to control arboviruses epidemics.

The developments in the area of nanomedicines is also promising new treatments for different diseases, improving the efficacy and bioavailability of drugs, with controlled release formulations that require optimal doses and consequently lesser adverse effects. This review discusses the current status of nanobiotechnology relevant to the control of arbovirus mosquito vectors, and highlights how it provides key tools for exploring new perspectives in the treatment of arboviruses.

\section{NANOTECHNOLOGY FOR ARBOVIRUS DETECTION AND CONTROL}

Several strategies have been applied to prevent proliferation of Aedes species using physical, biological, and chemical control approaches. Other methods under research and development, are also being studied, including the use of nanotechnology to produce repellent and larvicidal formulations that are more efficacious and less toxic. The development of nanotechnologybased sensors for rapid viral detection has also attracted the attention of scientific community (Figure 1).

\section{Biosensors}

Rapid diagnosis of important arboviruses-borne diseases such as dengue, chikungunya, zika, and yellow fever is essential in order to reduce and avoid further dissemination of the infections within the general population (Patterson et al., 2016). The WHO has emphasized the importance of developing point-of-care (POC) tests that are ASSURED (Affordable, Sensitive, Specific, Userfriendly, Robust and rapid, Equipment-free, and Deliverable) (Pashchenko et al., 2018). An ideal technique for the on-site detection of arboviruses should have these characteristics and enable early detection of the disease. Fast and timely diagnosis

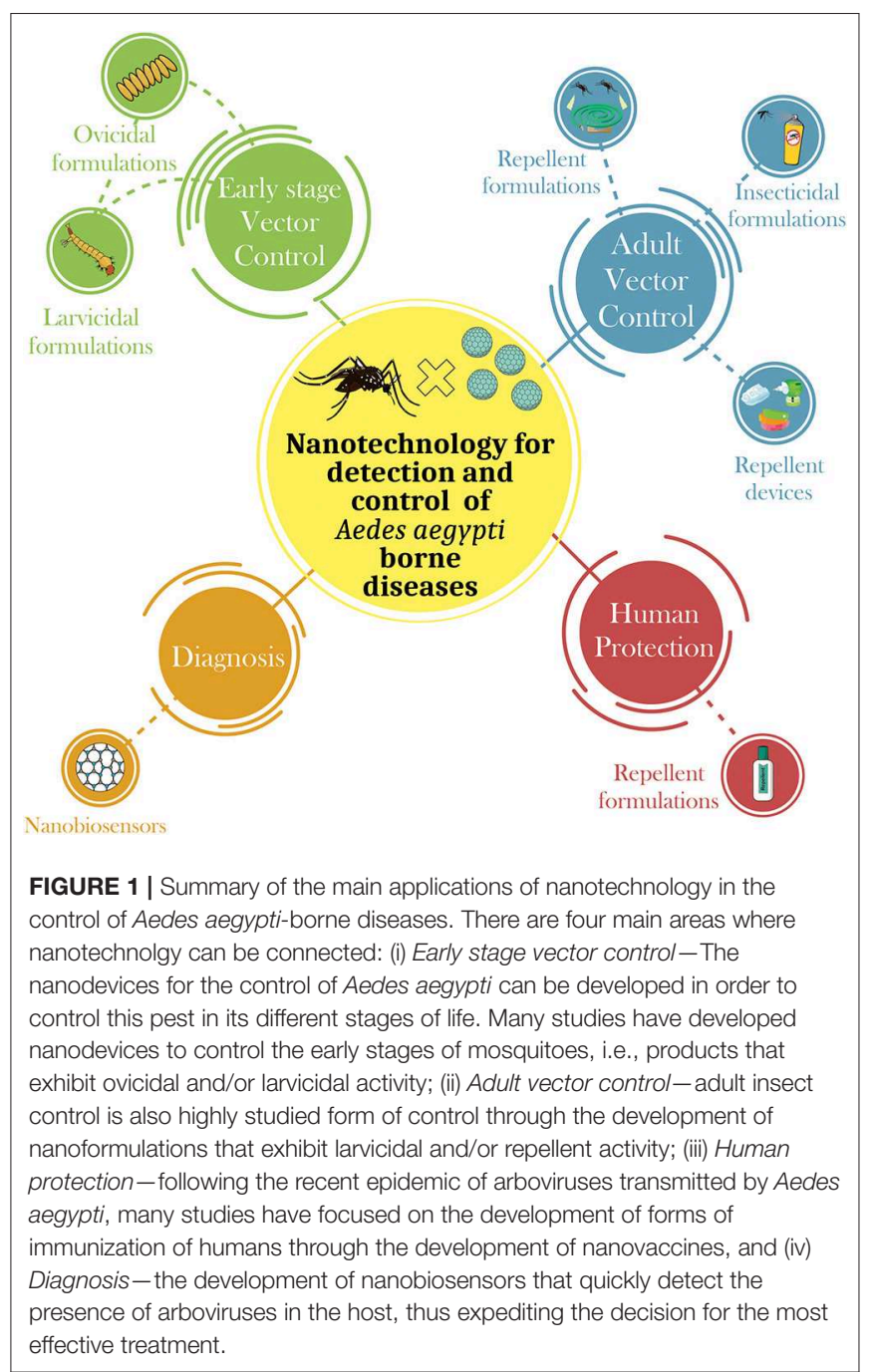

is crucial for the confirmation of viral infection so that it can be followed by clinical treatment, and necessary measures can be put in place for monitoring and protection of public health (Rashid and Yusof, 2018). Currently, diagnosis of the infections caused by arboviruses in the genus Flavivirus (family Flaviviridae) is often late, ineffective, and dependent on the clinical symptoms. The final decision on the infection generally requires a long waiting time, collection of samples from suspected patients (blood, urine, or saliva), transportation and preservation, and laboratory procedures by trained health staff.

Given such difficulties in the early detection of an impending epidemic of a viral infection, such as dengue, chikungunya, zika, and yellow fever (Nakata and Röst, 2015), there has been an urgent need for the improvement of existing tools and development of new biosensing technologies that are rapid, effective, and applicable in terms of real-time diagnosis. Biosensors are biologically-selective analytical devices that are able to recognize analytes in a complex sample matrix without the need for lengthy sample treatments. The biologically-selective part of biosensors enables them to produce highly specific 
responses by means of a transduction system that acts to convert the biological recognition into a quantifiable electrical signal (Figure 2). For the detection of arboviruses, the system must be able to identify low concentrations in complex sample matrices, such as blood, saliva, urine, and serum, without pretreatment or with minimal sample preparation.

The great advantage of a biosensor is that the bioreceptor interacts specifically with an analyte molecule. The specific interaction causes one or more physicochemical changes (production of ions, colored moieties, electrons, gases, heat, mass, or light) (Sethi, 1994). These responses can then be amplified and transformed into easily interpretable results. For the control and diagnosis of an endemic disease, an ideal biosensor device should be able to detect the arbovirus during all stages of infection, so the device must be designed to carry more than just one bioreceptor (multiplex sensing). Such features can be achieved using lateral-flow assays (LFAs) and lateral flow immunoassay (LFIA).

Several recent studies have used mainly LFAs as the basis for the construction of ASSURED biosensing devices. These assays can be performed using microfluidic technologies such as paperbased miniaturized devices that combine several recognition steps in a small area for naked-eye detection and quantification of compounds in complex mixtures, with the sample being collected on a test device and the results being displayed in real time (Koczula and Gallotta, 2016). Glucose, urine, and pregnancy test strips are examples of LFA devices, where the fluid containing the sample (blood, saliva, serum, etc.) moves by capillary action through various stages were antibodies and conjugated labels (nanoparticles, for instance) can interact and react to the fluid and, finally, show (sandwich assays) or not (competitive assays) a colored line at the test line position. More detailed information about LFAs can be found at (Sajid et al., 2015; Koczula and Gallotta, 2016; Carrell et al., 2019). Figure 3 provides a scheme of biosensor based on LFA where a colorimetric lateral flow biosensor (LFB) for the visual detection of dengue-1 RNA using dextrin-capped gold nanoparticle (AuNP) as label can be seen.

The detection of dengue and yellow fever has been performed with a platform for multiplexed pathogen detection employing

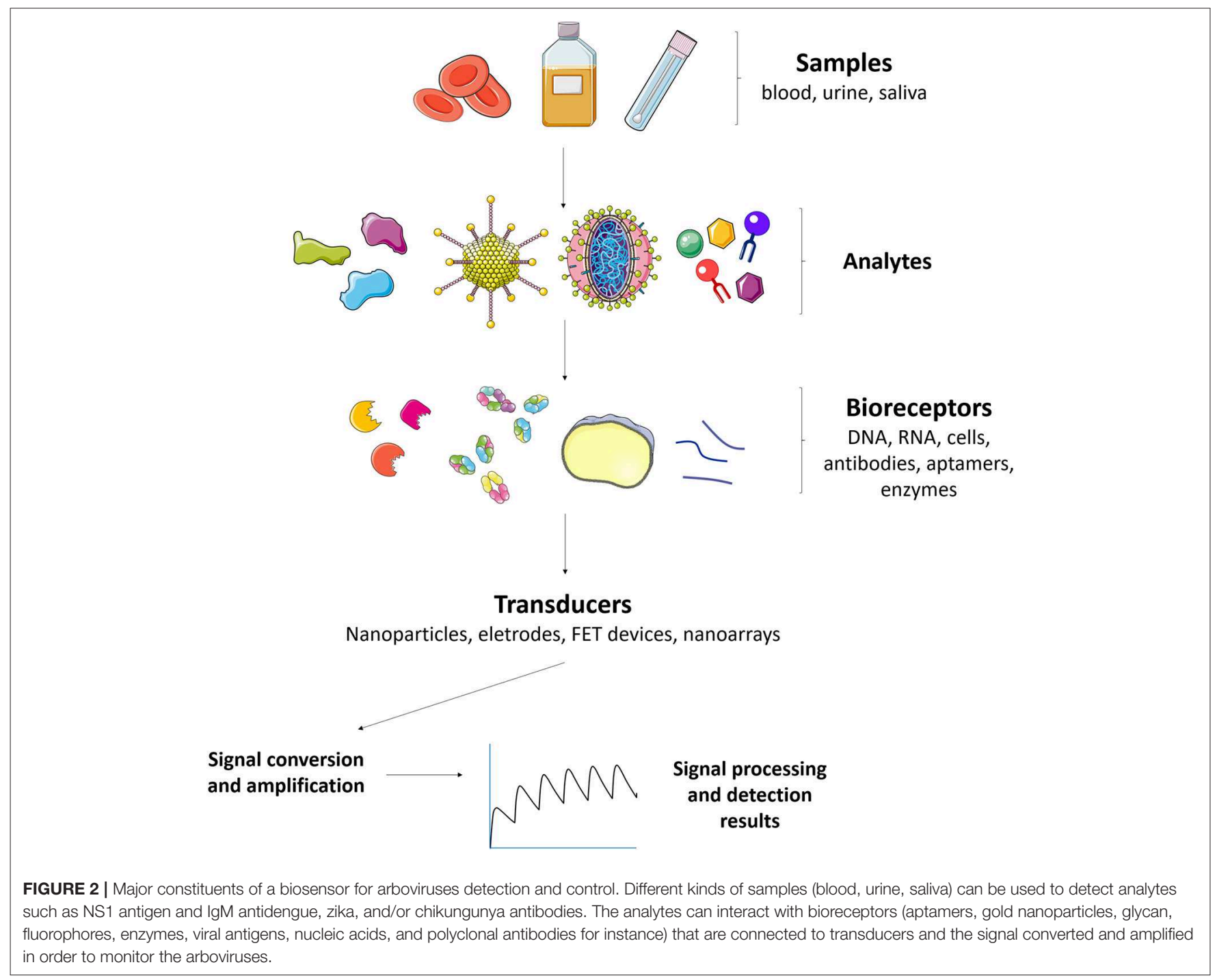




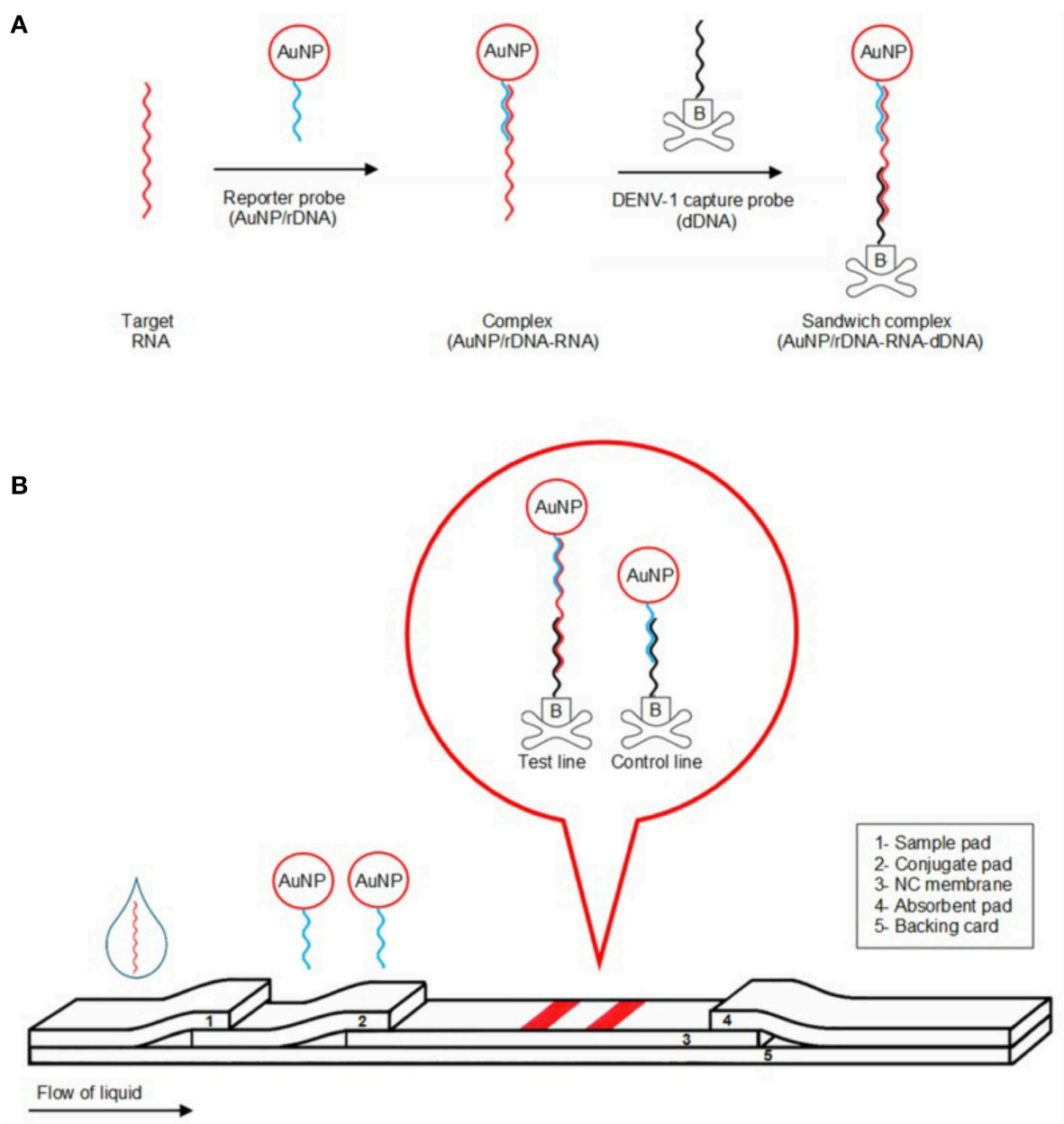

FIGURE 3 | Illustration of detection mechanism of the detection of dengue-1 RNA using dextrin-capped AuNP as label in a POC device. (A) Formation of AuNP/rDNA-RNA-dDNA sandwich complex. (B) Schematic of visual detection. Reprinted with permission from Yrad et al. (2019). Visual detection of dengue-1 RNA using gold nanoparticle-based lateral flow biosensor. Diagnostics 9:74.

multi-colored silver nanoplates (Yen et al., 2015) as demonstrated by Yen et al. (2015). In this study, the authors showed that the color of test lines could differentiate among different bioreceptors, with the analyses being performed in various ways, including the use of mobile phone applications. Current improvements in LFA technology are associated with the use of nanotechnological tools, such as lab-on-a-chip devices and nanoparticles that change color when aggregated. These improvements have significantly enhanced diagnosis sensitivity and selectivity.

Nawaz et al. (2018) reported a novel method for the detection, classification, and antibody screening of dengue virus, based on electrochemical impedance spectroscopy (EIS), involving protein recognition by means of a self-assembly process based on polymer matrix composites. However, as mentioned previously, it is very important to be able to achieve early detection of arbovirus infection but the biosensors had generally been designed to detect NS-type proteins that are only produced from the fifth day of infection onwards (Nawaz et al., 2018). Omar et al.
(2018) overcame this limitation by designing an optical sensor based on the surface plasmon resonance phenomenon, which was applied to the diagnosis of dengue virus structural E-protein that forms the coat of the host virus itself. This protein can be detected earlier, at the start of the immune system response to the infection (Omar et al., 2018).

Figure 4 shows the schematic immobilization of IgM in gold/Fe-MPA-NCCCTAB (3-mercaptopropionicacid - nanocellulose crystalline/hexadecyltrimethylammonium bromide, respectively)/EDC-N-hydroxysuccinimide (NHS) for early detection of dengue virus E-protein using surface plasmon resonance explored by Omar et al. (2018). By introducing IgM immobilized Fe-MPA-NCC-CTAB/EDC-NHS on a gold surface, it is possible to determine the E-protein concentration in a range of $0.0001-10 \mathrm{nM}$. The sensitivity found by optical sensor in contact with DENV is $39.96^{\circ} \mathrm{nM}^{-1}$ (Omar et al., 2018).

Vinayagam et al. (2018) reported the recognition of serotype-specific DENV employing multicolor triangular silver nanoparticles (TAg), which has the potential to be a 
A

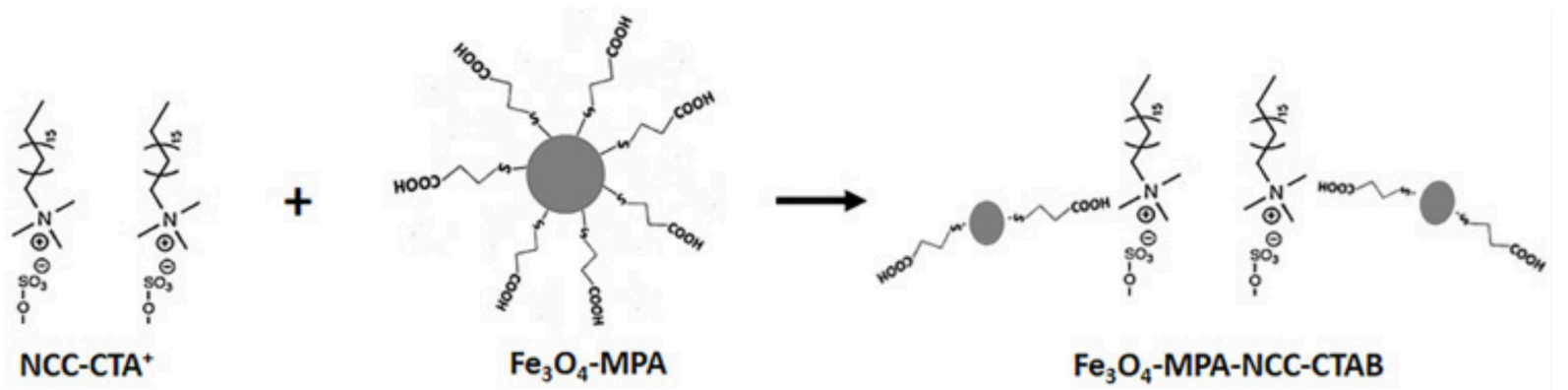

$e_{3} \mathrm{O}_{4}$-MPA-NCC-CTAB
B (a)

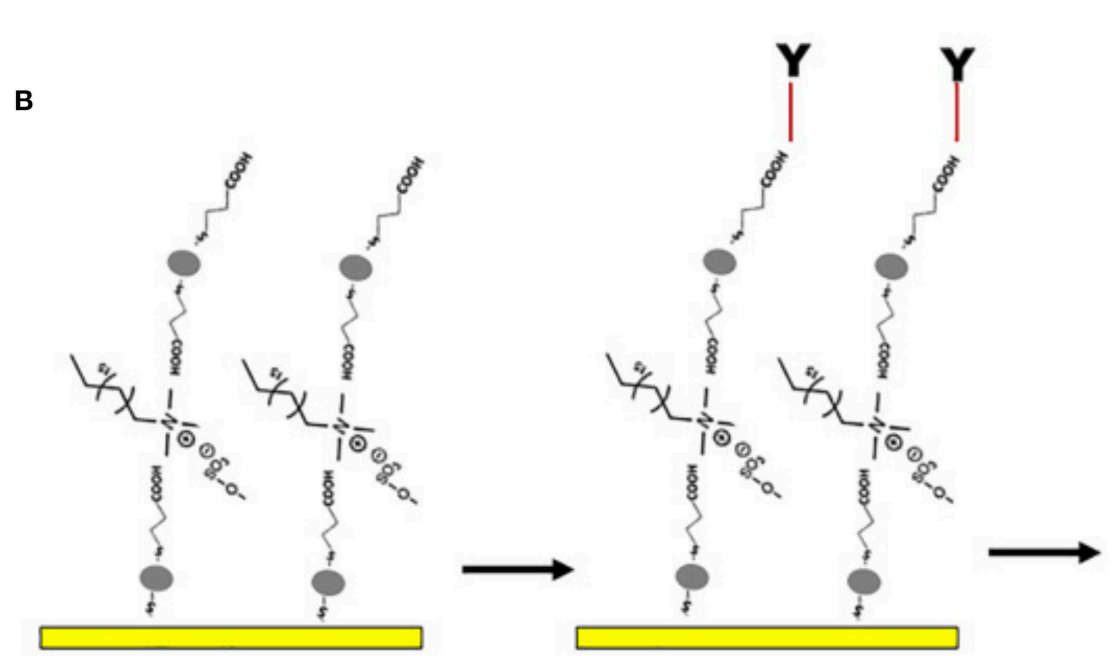

(b)

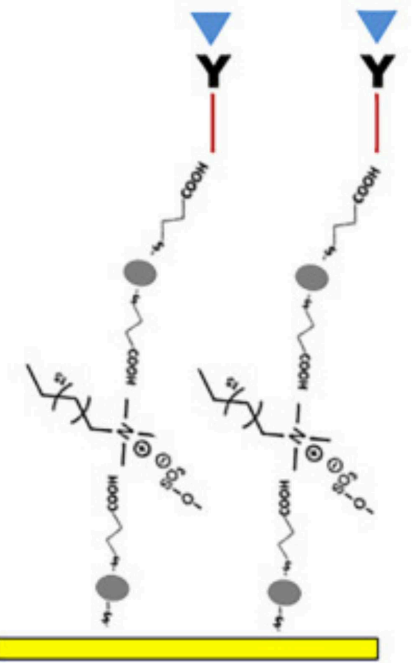

(c)

FIGURE 4 | (A) Illustration of possible mechanism for the preparation of Fe-MPA-NCC-CTAB composite aiming the dengue virus recognition (B) The sensor functionalization. (a) Surface activation of gold/Fe-MPA-NCC-CTAB layer, (b) Immobilize the IgM antibody via EDC-NHS cross-linker, (d) Injection of dengue E-protein solution. Reprinted with permission from Omar et al. (2018). Development of an optical sensor based on surface plasmon resonance phenomenon for diagnosis of dengue virus E-protein, Sensing and Bio-Sensing Research 20, 16-21.

powerful diagnosis technique that is able to differentiate between various serotypes. The color responses were established on the interaction of a TAg-DNA probe with a specific strand, resulting in the creation of a network association between the DNA probe and the dengue virus RNA, according to serotype. This was the first report of DNA conjugated to triangular silver nanoparticles, based on the $\mathrm{pH}$ reduction method. This biosensor has not yet been tested using real samples from infected patients, although the proposed technology appears to be very promising for use in clinical POC diagnostic testing (Vinayagam et al., 2018).

Other available methodologies and R\&D developments for the improvement and development of biosensing systems for the detection of arboviruses are shown in Table 1.

The recent increase in the cases of epidemic infections worldwide (Nicolini et al., 2017b) has also been matched by an increase in the available commercial biosensing devices and diagnostic methodologies. An excellent example is the invention designed by Kaushik and Nair (2018). The device is based on a modeling and electrochemical immunosensing approach for the detection of zika virus and offers an extremely low detection limit (picomolar). The biosensor is shaped to be worn on an individual's skin for infection screening. It matches the analyte measurement to the baseline in order to determine if an infection is present. After signal interpretation, the result is transmitted as an alert message. The device can be classified as a point-of-care biosensor, since it complies with the ASSURED features as proposed by the WHO.

The Ulisse Biomed SRL product portfolio includes a biosensor for the determination of an infection, and possible associated infections, caused by several viral pathogens, including zika, dengue, and chikungunya. The biosensor designed by Braga et al. provides a method for obtaining qualitative and quantitative data related to viral infections. This specific biosensor consists of an antigen (biologically active responsive element) bound covalently to the surface of one or more carbon nanotubes and/or metal nanoparticles present on part of a microelectrode surface, together with 
TABLE 1 | Main biosensors developed for the detection of arboviruses, together with their operational principles and applications.

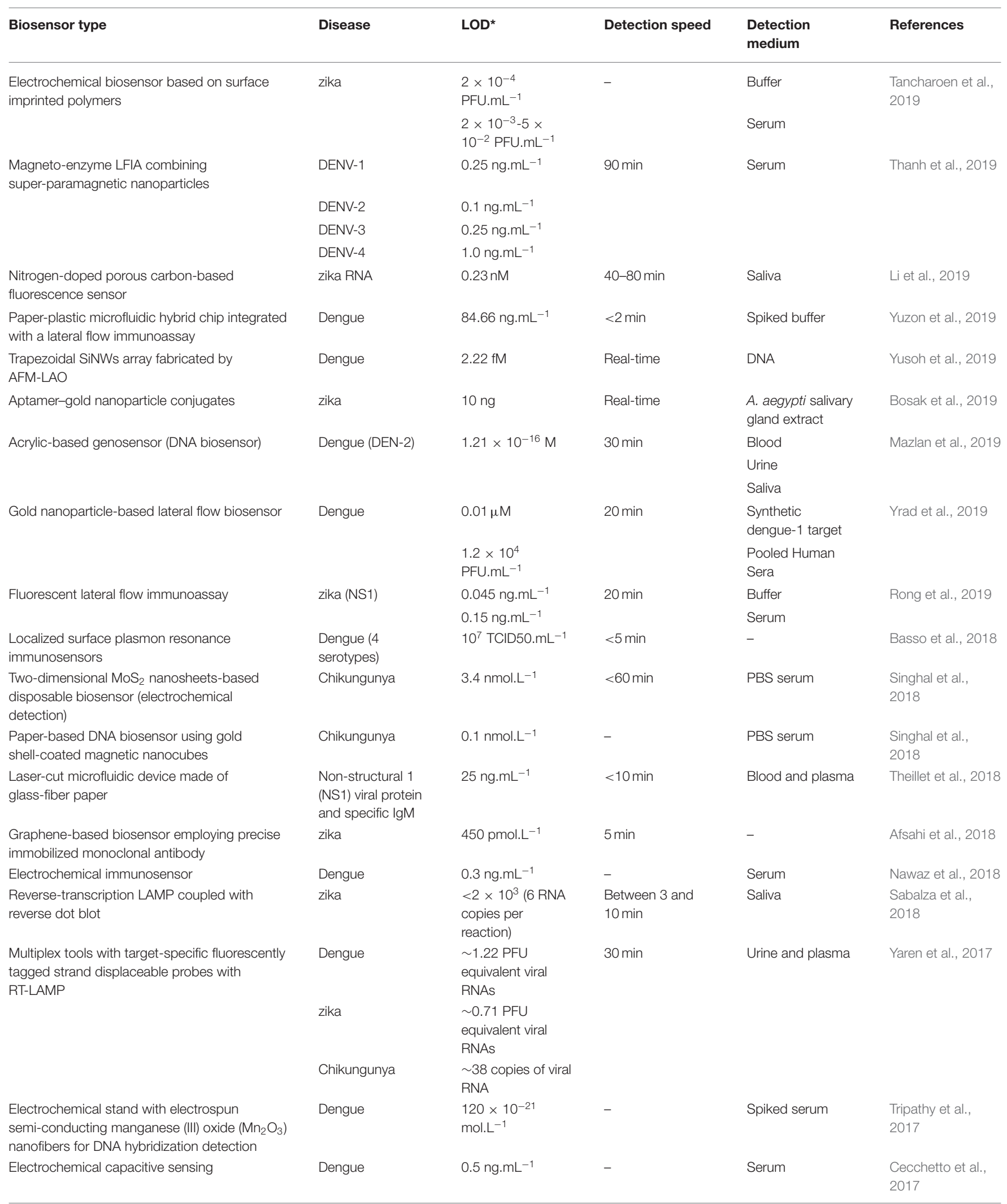


TABLE 1 | Continued

\begin{tabular}{|c|c|c|c|c|c|}
\hline Biosensor type & Disease & LOD* & Detection speed & $\begin{array}{l}\text { Detection } \\
\text { medium }\end{array}$ & References \\
\hline & zika & & & & \\
\hline & Chikungunya & & & & \\
\hline \multirow{3}{*}{$\begin{array}{l}\text { Coupling of reverse-transcription } \\
\text { loop-mediated isothermal amplification } \\
\text { (RT-LAMP) with the quenching of } \\
\text { unincorporated amplification signal reporters } \\
\text { (QUASR) technique }\end{array}$} & Dengue & $10^{3.4}$ copies. $\mu L^{-1}$ & $<40 \min$ & $\begin{array}{l}\text { Blood, urine, and } \\
\text { saliva }\end{array}$ & Priye et al., 2017 \\
\hline & zika & $\begin{array}{l}10^{5}-10^{2} \text { PFU } \\
\text { equivalent. } \mathrm{mL}^{-1} \\
\left(10^{4}-10^{1} \text { copies }\right. \\
\text { per rxn) } \\
10^{8}- \\
10^{3} \text { PFU. } \mathrm{mL}^{-1}\end{array}$ & $\begin{array}{l}7-15 \min \\
<40 \min \end{array}$ & & \\
\hline & Chikungunya & & & & \\
\hline \multirow[t]{2}{*}{$\begin{array}{l}\text { Surface-enhanced Raman spectroscopy } \\
\text { (SERS)-based sandwich immunoassays (LFA) }\end{array}$} & zika (NS1) & $0.72 \mathrm{ng} \cdot \mathrm{mL}^{-1}$ & $20 \mathrm{~min}$ & Serum & $\begin{array}{l}\text { Sánchez-Purrà } \\
\text { et al., } 2017\end{array}$ \\
\hline & Dengue & 7.67 ng.mL ${ }^{-1}$ & & & \\
\hline $\begin{array}{l}\text { Bead-based immunofluorescence assay on a } \\
\text { microfluidic dielectrophoresis platform }\end{array}$ & Dengue & $10^{4}$ PFU. $\mathrm{mL}^{-1}$ & $5 \min$ & - & $\begin{array}{l}\text { Iswardy et al., } \\
2017\end{array}$ \\
\hline $\begin{array}{l}\text { Optical caustic plasmonic light scattering } \\
\text { sensor }\end{array}$ & Dengue & 50 pg.mL $\mathrm{mL}^{-1}$ & $15 \min$ & Serum & García et al., 2017 \\
\hline \multirow[t]{2}{*}{$\begin{array}{l}\text { Carbon nanotube-based chemiresistor } \\
\text { functionalized with heparin }\end{array}$} & Yellow fever & $\begin{array}{l}8.4 \times 10^{2} \\
\text { TCID50. } \mathrm{mL}^{-1}\end{array}$ & $10 \min$ & - & Wasik et al., 2017 \\
\hline & Dengue & & & & \\
\hline \multirow{2}{*}{$\begin{array}{l}\text { Multiplexed assay on a nanostructured } \\
\text { plasmonic gold (pGOLD) platform }\end{array}$} & zika (NS1) & 0.33 lgG level & $120 \mathrm{~min}$ & Serum & Zhang et al., 2017 \\
\hline & & 0.30 lgA level & & & \\
\hline $\begin{array}{l}\text { Reverse transcription strand invasion-based } \\
\text { amplification (RT-SIBA) with fluorescence } \\
\text { detection }\end{array}$ & zika & $\begin{array}{l}5,000 \\
\text { copies. } \mathrm{mL}^{-1}\end{array}$ & $<30 \min$ & Lysis buffer & $\begin{array}{l}\text { Eboigbodin et al., } \\
2016\end{array}$ \\
\hline $\begin{array}{l}\text { Detection using isothermal amplification, AC } \\
\text { susceptometry, and magnetic nanoparticles }\end{array}$ & $\begin{array}{l}\text { zika virus } \\
\text { oligonucleotide }\end{array}$ & $1 \mathrm{aM}$ & $27 \min$ & Serum & Tian et al., 2016 \\
\hline $\begin{array}{l}\text { Reverse-transcription loop-mediated } \\
\text { isothermal amplification (RT-LAMP) }\end{array}$ & zika & 50-100 PFU.mL ${ }^{-1}$ & $40 \mathrm{~min}$ & Saliva & Song et al., 2016 \\
\hline $\begin{array}{l}\text { Lateral flow assay using multicolored silver } \\
\text { nanoparticles }\end{array}$ & Dengue & $150 \mathrm{ng} \cdot \mathrm{mL}^{-1}$ & - & Blood & Yen et al., 2015 \\
\hline Carbon nanotube-ink printed electrode & Dengue & $12 \mathrm{ng} \cdot \mathrm{mL}^{-1}$ & - & Serum & Dias et al., 2013 \\
\hline $\begin{array}{l}\text { Optical DNA biosensor based on square-planar } \\
\text { ethyl piperidine substituted nickel (II) salphen } \\
\text { complex }\end{array}$ & Dengue & $0.2 \mathrm{~mol} \mathrm{~L}^{-1}$ & $30-120 \mathrm{~min}$ & Saliva and urine & Ariffin et al., 2013 \\
\hline $\begin{array}{l}\text { Microfluidic system combined with microvalves } \\
\text { and micropumps for rapid DNA hybridization } \\
\text { using shuttle flow }\end{array}$ & $\begin{array}{l}\text { Dengue }(4 \\
\text { serotypes) }\end{array}$ & 100 pmol. $L^{-1}$ & $90 \mathrm{~s}$ & - & Huang et al., 2010 \\
\hline $\begin{array}{l}\text { Microfluidic chip that accomplish DNA/RNA } \\
\text { amplification, sample injection, and separation } \\
\text { of nucleic acid products }\end{array}$ & Dengue & - & $<5 \min$ & - & Huang et al., 2010 \\
\hline $\begin{array}{l}\text { Sensor-based microchip employing a magnetic } \\
\text { bead bioassay platform }\end{array}$ & $\begin{array}{l}\text { Dengue } \\
\text { (antidengue virus } \\
\text { lgG) }\end{array}$ & $100 \mathrm{pg} \cdot \mathrm{mL}^{-1}$ & - & - & Aytur et al., 2006 \\
\hline
\end{tabular}

*Limit of detection.

an electrically conducting part where a transduction system (sensor) converts the biochemical response into an electric signal (Braga et al., 2015).

Table 2 lists some of the published patents related to the improvement of biosensing tools and emerging new technologies for more efficient detection of analytes related to dengue, chikungunya, zika, and yellow fever.

The advancement of technology can show how to improve the ways to detect arboviruses with nano based-tools. However, just a few publications on the use of nano-tools has been 
TABLE 2 | Patents related to the detection and control of arboviruses.

\begin{tabular}{|c|c|c|c|c|c|}
\hline \multirow[t]{2}{*}{ Country } & \multirow[t]{2}{*}{ Company } & \multicolumn{4}{|l|}{ Product } \\
\hline & & technology & Year & Patent number & References \\
\hline United States & Mikrogen, GmbH & $\begin{array}{l}\text { Method for the immunological diagnosis of a } \\
\text { sample with a potential infection with an } \\
\text { arbovirus and test kits suitable for this purpose }\end{array}$ & 2019 & US2019/0227065A1 & Soutschek et al., 2019 \\
\hline United States & $\begin{array}{l}\text { The USA, as } \\
\text { represented by the } \\
\text { Secretary, Dept. } \\
\text { Of health and } \\
\text { human services }\end{array}$ & $\begin{array}{l}\text { Compositions and methods for the diagnosis } \\
\text { and treatment of zika virus infection }\end{array}$ & 2017 & WO2018152496A1 & $\begin{array}{l}\text { Akahata and Ueno, } \\
2017\end{array}$ \\
\hline United States & $\begin{array}{l}\text { University of } \\
\text { Central Florida } \\
\text { Research } \\
\text { Foundation, Inc. } \\
\text { (UCFRF) }\end{array}$ & $\begin{array}{l}\text { A payload reservoir comprising an insect } \\
\text { attractant or insect food source; and (b) A } \\
\text { detector conjugate comprising a gold } \\
\text { nanoparticle conjugated to a specific detector } \\
\text { molecule that binds specifically to a protein } \\
\text { present in the saliva of a specific insect to be } \\
\text { detected }\end{array}$ & 2018 & US20180231550A & $\begin{array}{l}\text { Willenberg and Seal, } \\
2018\end{array}$ \\
\hline United States & $\begin{array}{l}\text { The Hong Kong } \\
\text { polytechnic } \\
\text { university }\end{array}$ & $\begin{array}{l}\text { Microarray design of hybrid upconversion } \\
\text { nanoparticles on a nanoporous anodized } \\
\text { alumina membrane heterogeneous assay for } \\
\text { simultaneous detection of multiple } \\
\text { oligonucleotides }\end{array}$ & 2018 & $\begin{array}{l}\text { US2018/0246084 } \\
\text { A1 }\end{array}$ & Hao et al., 2018 \\
\hline United States & Sympano, Inc. & $\begin{array}{l}\text { Nano-field electrical Sensor for Biomarkes and } \\
\text { other targets analytes by determining } \\
\text { impedance in bodily fluid on nanoporous } \\
\text { membrane }\end{array}$ & & $\begin{array}{l}\text { US2018/0067107 } \\
\text { A1 }\end{array}$ & Barrett et al., 2018 \\
\hline $\begin{array}{l}\text { China/ } \\
\text { United States }\end{array}$ & $\begin{array}{l}\text { Ulisse Biomed } \\
\text { SRL }\end{array}$ & $\begin{array}{l}\text { Biosensors for the detection of infection and } \\
\text { associated maladies }\end{array}$ & 2017 & $\begin{array}{l}\text { CN106461667A } \\
\text { US20170212116A1 }\end{array}$ & Braga et al., 2015 \\
\hline United States & DexCom, Inc. & $\begin{array}{l}\text { Transcutaneous analyte sensor for } \\
\text { transcutaneous measurement of glucose in a } \\
\text { host }\end{array}$ & 2018 & US7654956B2 & Brister et al., 2012 \\
\hline Spain & $\begin{array}{l}\text { Universidad } \\
\text { complutense de } \\
\text { Madrid }\end{array}$ & Biosensor for the detection of nucleic acids & 2017 & ES2580138B2 & Cabarcos et al., 2017 \\
\hline United States & $\begin{array}{l}\text { University of } \\
\text { Ottawa, University } \\
\text { of Malaya }\end{array}$ & $\begin{array}{l}\text { Long-range surface plasmon-polariton } \\
\text { biosensor }\end{array}$ & 2018 & WO2018090125A1 & Berini and Wong, 2018 \\
\hline United States & $\begin{array}{l}\text { Florida } \\
\text { International } \\
\text { University }\end{array}$ & $\begin{array}{l}\text { Electrochemical sensing device based on } \\
\text { nano-devices for fast zika Virus detection }\end{array}$ & 2018 & US10012645B2 & Kaushik and Nair, 2018 \\
\hline United States & $\begin{array}{l}\text { San Diego State } \\
\text { University (SDSU) } \\
\text { Foundation }\end{array}$ & $\begin{array}{l}\text { Cell-based devices for track small molecules } \\
\text { that restrain enzymes }\end{array}$ & 2018 & US10006077B2 & Wolkowicz, 2018 \\
\hline United States & $\begin{array}{l}\text { Eccrine Systems, } \\
\text { Inc. }\end{array}$ & $\begin{array}{l}\text { Biosensing device aimed to be used in humans } \\
\text { skin to track an infection by one or more } \\
\text { antigens }\end{array}$ & 2018 & WO2018026931A1 & Beech et al., 2018 \\
\hline United States & $\begin{array}{l}\text { Aviana molecular } \\
\text { technologies, LLC }\end{array}$ & $\begin{array}{l}\text { Multiplex acoustical biosensor with higher } \\
\text { sensitivity }\end{array}$ & 2011 & US20110136262A1 & Ragavan et al., 2011 \\
\hline United States & $\begin{array}{l}\text { Purdue research } \\
\text { foundation }\end{array}$ & $\begin{array}{l}\text { Electrochemical biosensor for RNA and DNA } \\
\text { sensing }\end{array}$ & 2017 & US20170107565A1 & $\begin{array}{l}\text { Marinero-Caceres } \\
\text { et al., } 2017\end{array}$ \\
\hline United States & $\begin{array}{l}\text { Aviana molecular } \\
\text { technologies, LLC }\end{array}$ & $\begin{array}{l}\text { Biocoated piezoelectric biosensor platform for } \\
\text { point-of-care diagnostic use }\end{array}$ & 2015 & US20150111765A1 & $\begin{array}{l}\text { Laury-Kleintop and } \\
\text { Rutner, } 2015\end{array}$ \\
\hline $\begin{array}{l}\text { France/ } \\
\text { United States }\end{array}$ & $\begin{array}{l}\text { Cornell Research } \\
\text { Foundation, Inc. }\end{array}$ & Microfluidic biosensor and methods of use & 2005 & WO2005084404A2 & Baeumner et al., 2005 \\
\hline $\begin{array}{l}\text { Australia/ } \\
\text { United States }\end{array}$ & $\begin{array}{l}\text { Lifeprint Australia } \\
\text { Pty Ltd. }\end{array}$ & $\begin{array}{l}\text { Auto-feedback loop biosensor-signal } \\
\text { amplification auto-feedback loop for the } \\
\text { detection of a target analyte in a sample }\end{array}$ & 2009 & WO2009152566A1 & $\begin{array}{l}\text { Fletcher and Milligan, } \\
2009\end{array}$ \\
\hline United States & UT-Battelle, LLC & $\begin{array}{l}\text { Biosensor which has multiple functions and } \\
\text { broad spectrum and methods of utilization }\end{array}$ & 2004 & USO06743581B1 & Vo-Dinh, 2004 \\
\hline
\end{tabular}


clearly demonstrated. Nanosensors have the potential to be allies in the early detection of Aedes aegypti-borne diseases by offering novel approaches to achieve sensitive, specific, and stable recognition in complex matrices in quick or real-time diagnostics. Although some variations in synthesis protocols can still be tested to improve the productivity and efficiency of nanomaterials for diagnostic applications, more research on the way lab-to-practical nanodiagnostics is needed. Not only more research must be done on nanosensors for A. aegypitborne diseases, but the upscale of the applicability is urgently necessary, as shown by the few patents filed for this purpose (Table 2). One of the ways for this accomplishment is to narrow the scientific boundaries between disciplines such as chemistry, sociology, bio, and nanotechnology and information technology. A good example that results from this new multidisciplinary approach is the smartphones-based POC devices, as previously cited. They are a real and promising novel tool for flaviviruses detection without complex instruments, since, in a simple way, the blood sample can be analyzed under $40 \mathrm{~min}$ (Priye et al., 2017; Rong et al., 2019). Despite the advances, still, there is an urgent need for proper and precise use of nanosensors in hospitals, field, and to prevent these potential health risk diseases.

\section{Insect Repellents}

The development of new nanotechnology-based formulations for the encapsulation of natural and synthetic repellents is an important strategy for obtaining systems that are more effective and have fewer undesirable impacts. These sustainedrelease formulations provide controlled or slow release of active agents into the environment, increasing the duration of action and reducing human exposure to the agent (for example, by permeation through the skin). Encapsulation also protects the active agent against premature degradation caused by the effects of light, temperature, oxidation, and humidity, among others (Tavares et al., 2018). Numerous matrices (synthetic and natural) can be used for the preparation of carrier systems, including polymers, proteins, lipids, polysaccharides, and others. It should be noted that the main desirable characteristics of such matrices are biocompatibility and biodegradability, as well as low cost (Barradas et al., 2016).

Gomes et al. encapsulated DEET in polymeric nanospheres, resulting in particles with an average diameter of $114 \pm 37 \mathrm{~nm}$, low polydispersion index, and stability as a function of time. The sustained release of nanoencapsulated DEET provided repellency for over $9 \mathrm{~h}$, which was longer than obtained using free DEET. The results showed that the release mechanism was temperature dependent, which the authors highlighted as having great potential, since the release rate could be adjusted by alteration of temperature (Gomes et al., 2018).

Silva et al. (2019) encapsulated essential oils of Piper aduncum L. and Piper hispidinervum in gelatin nanoparticles and evaluated effect against Aedes aegypti Linn. Results showed a high encapsulation efficiency of the EOs (around 80\%), average size around $100-200 \mathrm{~nm}$, zeta potential around $-40 \mathrm{mV}$. Both encapsulated EOs reached lethal dosages within $24 \mathrm{~h}$ of exposure and total mortality of the tested pests (Silva et al., 2019).
Forgearin et al. prepared and characterized permethrinloaded lipid nanocapsules and tested their application as repellents in clothes. The formulations presented a mean particle diameter of $201 \pm 4 \mathrm{~nm}$, with a monomodal size distribution and permethrin content of $4.6 \pm 0.1 \mathrm{mg} / \mathrm{mL}$. It was observed that even after washing and with the action of temperature, the polyester fabrics containing the nanoparticles had higher concentrations of permethrin, compared to those containing only the free compound. The results showed that the innovative repellent spray composed of the nanoparticle formulation was useful for the impregnation of clothes and was promising for the protection of an individual against insects (Forgearini et al., 2016).

Werdin González et al. prepared and characterized polymeric nanoparticles (composed of PEG and chitosan) for the encapsulation of essential oils (geranium and bergamot). Evaluation was also made of the acute and residual larvicidal activities of the formulations against Culex pipiens. Physicochemical characterization showed that the PEG nanoparticles containing the essential oils had a mean size of $<255 \mathrm{~nm}$ and provided encapsulation efficiencies between 68 and $77 \%$, while the chitosan nanoparticles presented a mean size of $<535 \mathrm{~nm}$ and encapsulation efficiencies between 22 and $38 \%$. Both systems showed high larvicidal activity (acute and residual), with the chitosan-based formulations having the best effects. These findings demonstrated the potential of polymeric nanoparticles containing essential oils for use as eco-friendly larvicidal products (Werdin González et al., 2017).

Silva et al. studied the encapsulation of the essential oils of Piper aduncum L. and Piper hispidinervum C. in gelatin nanoparticles, with evaluation of the biological effects against Aedes aegypti. The encapsulation efficiencies exceeded $80 \%$, and the particles were spherical, monodispersed, and smaller than $100 \mathrm{~nm}$ in size. Both of the encapsulated essential oils provided lethal effects within $24 \mathrm{~h}$ of exposure, with Aedes aegypti mortality greater than $80 \%$ (Silva et al., 2019).

It should be noted that the search for new formulations has also led to patenting. For example, patent BR1020180168665 describes the preparation and characterization of nanostructured lipid carriers (NLCs) and nanoemulsions containing citronella and neem oil, for the control of insects such as Aedes aegypti. The results showed that both the nanoemulsions and the NLCs loaded with the essential oils caused $100 \%$ mortality of $A$. aegypti larvae during the first day of exposure, while the NLCs without essential oil induced $100 \%$ mortality after 10 days of exposure. Both carriers showed satisfactory efficacy in the control of $A$. aegypti larvae (Fraceto et al., 2018).

The patent WO2017143421A1 describes the invention of cosmetic formulations for use as topical insect repellents, employing polymeric micelles, nanoemulsions, and solid lipid nanoparticles containing active repellent substances. Nanoencapsulation techniques were used to produce systems consisting of nanostructures with stable hydrophobic and hydrophilic chains. The formulations presented sustained release of the active substances, consequently providing long duration of action of the repellents, together with greater safety (Paula et al., 2017). 
The patent US20190160016A1 present an invention to a nanoparticle composition comprising one or more $\beta$-triketones selected from Leptospermum scoparium botanical extract. The prepared system presented high insecticidal activity against ecotoparasites, and according to the inventors can also be applied to repel insects like Aedes aegypti (Thomas, 2019)

Table 3 presents other studies concerning the use of formulations based on micro/nanotechnology for the encapsulation of compounds (natural and synthetic) presenting repellent activity.

DEET is currently considered a "gold standard" due to its outstanding protection against mosquitoes and other biting insects. It is the most common active ingredient in all commercially available repellents and is used as a comparative for other substances (Khater et al., 2019). However, due to indiscriminate use has suffered resistance effects, leading to loss of formulations effectiveness. In addition, due to its toxicity has raised health and environmental concerns Thus, the search for natural alternative repellents as well as new molecules is necessary. This is the case of compound IR3535, one of the newest products with odorless and non-toxic characteristics, which is recommended for children over 6 months of age and pregnant women (Benelli et al., 2018a).

It is in this scenario of innovation and search for new solutions that nanotechnology applies. It is becoming increasingly necessary to develop formulations that increase the repellent's longevity by controlling delivery and evaporation rate. In addition, the different applications forms such as sprays, creams, lotions, aerosols, oils, adhesives, protective clothing, treated nets, among others, is very important in order to ensure options for people living in endemic areas (Tavares et al., 2018; Agnihotri et al., 2019). Thus, encapsulation in micro/nanoparticles, cyclodextrins, micelles, hydrogels among others constitutes an approach to modify the physicochemical properties of encapsulated repellents. When applied in topical formulations or in personal protective clothes, for example, they have been shown to be more effective in increasing repellency time and also in reducing dermal absorption, improving the safety profiles of these products (Ahmed et al., 2019; Osanloo et al., 2019). Innovative nanotechnology-based formulations should be followed by safety and efficacy studies, as this will increase consumer confidence in this new formulations (Hameed et al., 2019).

\section{Larvicidal and Ovicidal Nanoparticles}

The green or biological synthesis of nanoparticles, also called biogenic synthesis, can offer advantages over the classical nanotechnological techniques currently employed. The new synthesis methods are economical, fast, and less expensive, and are performed at ambient temperature and pressure. In contrast, standard physical and chemical techniques typically involve high energy consumption, due to the need for high pressures and temperatures (Benelli et al., 2018b). In addition, potentially harmful reagents and solvent are not used in green synthesis methods, because the reducing and stabilizing agents are substituted by molecules produced by living organisms (Kumar et al., 2015). These agents can be extracted from bacteria, fungi, yeasts, algae, or plants (Sintubin et al., 2012). The technique can be used to produce nanoparticles composed of metals, metal oxides, silica, and carbon (Benelli et al., 2016).

Recent studies have reported the synthesis of various nanoparticles using different natural extracts, with demonstration of the larvicidal, ovicidal, and mosquiticidal activities of these nanoparticles. Udayabhanu et al. observed the larvicidal effect of titanium dioxide nanoparticles $\left(\mathrm{TiO}_{2} \mathrm{NPs}\right)$ synthesized using an aqueous extract of Euphorbia hirta leaves against the larvae of Aedes aegypti $\left(\mathrm{LC}_{50}=13.2 \mathrm{mg} / \mathrm{L}\right)$ and Culex quinquefasciatus $\left(\mathrm{LC}_{50}=6.89 \mathrm{mg} / \mathrm{L}\right.$ ) (Udayabhanu et al., 2018).

Another study proposed the green synthesis of Ag NPs for use as an environmentally-friendly alternative to pyrethroid and carbamate larvicides. Silver nanoparticles synthesized from extracts of the Quisqualis indica plant showed high toxicity against the vectors of filariasis, zika virus, and malaria. In addition, toxicity tests employing three non-target organisms indicated low toxicity of these systems (Govindarajan et al., 2016).

The patent databases include inventions that describe methods of green synthesis of metal nanoparticles and metal oxides, with broad applications in consumer products, medicines, pharmaceuticals, and other biomedical products (Hoag et al., 2011; Liu et al., 2013; Yujia et al., 2015; Awad et al., 2016). There have been several reports concerning vector control using biogenic nanoparticles (Table 4), indicating the promising potential of these nanoparticles that are both environmentallyfriendly and highly effective for vector control.

\section{GAPS, OBSTACLES, AND CONCLUSIONS}

The potential application of nano-based formulations in the field of arboviruses management was investigated by analyzing the number of publications in the last ten years. The results revealed that around 1000 articles were published worldwide, which an exponential trend in publication numbers after 2016, mainly for researches related to zika and chikungunya. Overall, many publications have shown that nanotechnology has led to rapid advancements in the development of pesticides, repellents, drug delivery system and diagnostic devices for arboviruses management. However, the clinical translational of nano-based formulations has some bottlenecks that hinders the broad acceptance and commercialization of these products (Hua et al., 2018; Soares et al., 2018). Also, it's already known, that nanomaterials, independently of their composition and method of production, have new properties, which are not observed by their bulk materials (Laux et al., 2018). These novel properties have brought innovative solutions due their flexibleness, responsiveness and possibility of functionalization, the last one, which is very useful for drug targeting delivery (Jeevanandam et al., 2018). However, the behavior, fate, bioavailability nanomaterials in the environment and toxicity of non-target organisms should be better understood the possible environmental impacts (Dinda, 2018).

Much debate still exists regarding the legislation of nanomaterials, which is in an early stage of development. 
TABLE 3 | Formulations based on modified release systems for the encapsulation of active agents with insect repellent properties.

\begin{tabular}{|c|c|c|c|c|}
\hline Systems & Matrices & Active agents & Main characteristics & References \\
\hline $\begin{array}{l}\text { Polymeric } \\
\text { nanoparticles }\end{array}$ & $\begin{array}{l}\text { Poly(ethylene } \\
\text { glycol) (PEG) }\end{array}$ & Diethylphenylacetamide (DEPA) & $\begin{array}{l}\text { Diameter: } 149 \pm 1.06 \mathrm{~nm} \text {; Properties: } 5 \text {-fold decrease of } \\
\text { median lethal indices }\left(\mathrm{LC}_{50}\right) \text {, compared to free DEPA }\end{array}$ & Balaji et al., 2017 \\
\hline $\begin{array}{l}\text { Polymeric } \\
\text { nanospheres }\end{array}$ & $\begin{array}{l}\text { Poly(n-butyl } \\
\text { methacrylate- } \\
\text { co-methyl } \\
\text { methacrylate) }\end{array}$ & N,N-diethyl-m-toluamide (DEET) & $\begin{array}{l}\text { Diameter: } 114 \pm 37 \mathrm{~nm} \text {. } \\
\text { Properties: release rate of the encapsulated DEET provides } \\
\text { repellency for over } 9 \mathrm{~h} \text { and is and more controlled when } \\
\text { compared to the free DEET }\end{array}$ & $\begin{array}{l}\text { Gomes et al., } \\
2018\end{array}$ \\
\hline Nanoemulsion & $\begin{array}{l}\text { Polaxamer } \\
407\end{array}$ & $\begin{array}{l}\text { Ethyl butylacetylaminopropionate } \\
\text { (IR3535) }\end{array}$ & $\begin{array}{l}\text { Diameter: } \pm 200 \mathrm{~nm} \text {; } \\
\text { Properties: Nanoemulsion less retained by the epidermis and } \\
\text { not toxic to the cells }\end{array}$ & Pinto et al., 2017 \\
\hline Gel/Nanoparticle & Chitosan & $\begin{array}{l}\text { Zanthoxylum acanthopodium } \\
\text { essential oil (ZA EO) }\end{array}$ & $\begin{array}{l}\text { Encapsulation efficiency of } 96.64 \% \text {; Properties: Reduction in } \\
\text { essential oil permeation in in vitro membrane study and } \\
\text { mosquito repellent activity against Aedes aegypti with } \\
\text { protection time of } 2 \mathrm{~h}\end{array}$ & Sharma, 2019 \\
\hline $\begin{array}{l}\text { Polymeric } \\
\text { nanoparticles }\end{array}$ & $\begin{array}{l}\text { Polyethylene } \\
\text { glycol }\end{array}$ & Quercetin & $\begin{array}{l}\text { Diameter: } 124.0 \pm 1.1 \mathrm{~nm} \text {; Properties: Stability at } 4^{\circ} \mathrm{C} \text {, } \\
\text { affected larval Aedes aegypti development, less toxic than } \\
\text { non-encapsulated quercetin toward C. vulgaris (green alga) }\end{array}$ & $\begin{array}{l}\text { Pessoa et al., } \\
2018\end{array}$ \\
\hline $\begin{array}{l}\text { Polymeric } \\
\text { micelles }\end{array}$ & $\begin{array}{l}\text { PEG and } \\
\text { PLGA }\end{array}$ & Pyrethrins & $\begin{array}{l}\text { Diameter: } 140-320 \mathrm{~nm} \text {. Properties: Protection against } \\
\text { ultraviolet degradation (at } 26^{\circ} \mathrm{C} \text { ) and high larvicidal activity } \\
\text { against Culex pipiens pallens }\end{array}$ & Zhang et al., 2018 \\
\hline $\begin{array}{l}\text { Polymeric } \\
\text { microparticles }\end{array}$ & Gum arabic & Essential oils and DEET & $\begin{array}{l}\text { Diameter: } 1-68 \mathrm{~mm} \text {; Properties: Spherical shapes and cotton } \\
\text { fabric impregnated with system presentend better insect } \\
\text { repellency, compared to DEET }\end{array}$ & $\begin{array}{l}\text { Eyupoglu et al., } \\
2018\end{array}$ \\
\hline Nanoparticles & Chitosan & Siparuna guianensis essential oil & $\begin{array}{l}\text { Diameter: } 268 \pm 3.4 \mathrm{~nm} \text {; Encapsulation efficiency } \\
84.8-88.0 \% \\
\text { Properties: } 100 \% \text { mortality during the first week and provides } \\
\text { Against Aedes aegypti mosquito larvae }\end{array}$ & $\begin{array}{l}\text { Ferreira et al., } \\
2019\end{array}$ \\
\hline $\begin{array}{l}\text { Polymeric } \\
\text { nanoparticles }\end{array}$ & $\begin{array}{l}\text { Polaxamer } \\
407\end{array}$ & $\begin{array}{l}\text { Eugenol, 1,8-cineole, geraniol, } \\
\text { linalool, carvacrol, } \alpha \text {-terpineol, } \\
\text { citronellol, thymol, and menthol }\end{array}$ & $\begin{array}{l}\text { Diameter: Around } 40 \mathrm{~nm} \text {; Properties: Mortalities ranging from } \\
30 \text { to } 60 \% \text { against insects with linalool and 1,8-cineole being } \\
\text { most effective }\end{array}$ & Lucia et al., 2017 \\
\hline $\begin{array}{l}\text { Polymeric } \\
\text { microparticles }\end{array}$ & Cellulose & N,N-diethyl-m-toluamide (DEET) & $\begin{array}{l}\text { Encapsulation efficiency of } 98 \% \text {. } \\
\text { Properties: A significant reduction in release rate of DEET }\end{array}$ & Kadam et al., 2019 \\
\hline $\begin{array}{l}\text { Inclusion } \\
\text { complexes }\end{array}$ & $\begin{array}{l}\beta- \\
\text { Cyclodextrin }\end{array}$ & Lippia gracilis essential oil & $\begin{array}{l}\text { Inclusion complex formation by kneading and co-evaporation } \\
\text { with essential oil content } \sim 15 \% \text {; } \\
\text { Properties: } \text { LC }_{50} \text { of } 33 \text { ppm toward Aedes aegypti larvae and } \\
\text { inclusion complex was not harmful to non-target organisms }\end{array}$ & Galvão et al., 2018 \\
\hline $\begin{array}{l}\text { Polymeric } \\
\text { micropartices }\end{array}$ & $\begin{array}{l}\text { Carboxy- } \\
\text { methylcellulose } \\
(\mathrm{CMC})\end{array}$ & $\begin{array}{l}\text { Essential oils (Alpinia galanga, } \\
\text { Citrus grandis, and C. } \\
\text { aurantifolia), and DEET }\end{array}$ & $\begin{array}{l}\text { Diameter: } 4-200 \mu \mathrm{m} \text {. Properties: The same period of } \\
\text { repellent activity for essential oil encapsulated in comparison } \\
\text { with microencapsulated DEET. Extended duration of repellent } \\
\text { activity (between } 1 \text { and } 2 \mathrm{~h} \text { ) compared with commercial } \\
\text { formulations }\end{array}$ & Misni et al., 2017 \\
\hline Nanoemulsion & Tween 80 & Vitex negundo L. essential oil & $\begin{array}{l}\text { Diameter: < } 200 \mathrm{~nm} \text {; Properties: Nanoemulsion with higher } \\
\text { larvicidal activity (Aedes aegypti) compared with only essential } \\
\text { oil; }\end{array}$ & $\begin{array}{l}\text { Balasubramani } \\
\text { et al., } 2017\end{array}$ \\
\hline Nanoemulsion & Tween 80 & Ocimum sanctum essential oil & $\begin{array}{l}\text { Diameter: } 50-300 \mathrm{~nm} \text {; Properties: Nanoemulsion with } \\
\text { potential insecticidal effect against Aedes aegypti and C. } \\
\text { quinquefaciatus adults }\end{array}$ & Ramar et al., 2017 \\
\hline Nanofibrous & Cellulose & Citriodiol (CD) & $\begin{array}{l}\text { Properties: Nanofibrous presented more prolonged repellency } \\
\text { ( } 34 \text { days) than monolithic ones in experiments using Aedes } \\
\text { aegipty }\end{array}$ & Muñoz et al., 2019 \\
\hline
\end{tabular}

In addition, there is a lack of a clear definition of nanomaterials, lack of standard methods for assessment of pharmacology, toxicology and efficacy evaluation of nano-based formulations and lack of worldwide network for gathering and sharing pertinent information. According to Schnell-Inderst et al. (2018) 12\% of the documents related to the test of medical devices are written by academics and the regulators write the rest. In addition, there is a low number of experts in nanomaterials in regulatory agencies, resulting in the delayed development of these documents. Another issue is that FDA use the traditional regulatory frameworks to approve products, which contains nanomaterials (Jones et al., 2019). Nano-based formulations are evaluated by FDA using caseby-case approach, through combination product framework 
TABLE 4 | Biogenic nanoparticles tested for the control of disease vectors.

\begin{tabular}{|c|c|c|c|c|c|}
\hline Name & Action & Organism species & $\begin{array}{l}\mathrm{LC}_{50} / \mathrm{LC}_{90} \text { in } \\
\text { A. aegypti }\end{array}$ & Treatment time & References \\
\hline AgNP & $\begin{array}{l}\text { Larvicidal property } \\
\text { against fourth instar } \\
\text { larvae of Aedes aegypti }\end{array}$ & Apple extract & $\begin{array}{l}\text { AgNPs }-\mathrm{T} 15.76 / 27.7 \\
\text { ppm } \\
\text { AgNPs -RT } \\
\text { 29.81/42.3 ppm }\end{array}$ & $24 \mathrm{~h}$ & Ali et al., 2017 \\
\hline AgNP & $\begin{array}{l}\text { Ovicidal activity against } \\
\text { Aedes aegypti }\end{array}$ & $\begin{array}{l}\text { Bauhinea acumiata leaf } \\
\text { powder aqueous } \\
\text { extract }\end{array}$ & $27.19 / 52.32 \mu \mathrm{g} \cdot \mathrm{mL}^{-1}$ & $24 \mathrm{~h}$ & Alharbi et al., 2018 \\
\hline AgNP & $\begin{array}{l}\text { Larvicidal activity } \\
\text { against Aedes aegypti, } \\
\text { Anopheles stephensi, } \\
\text { and Culex } \\
\text { quinquefasciatus }\end{array}$ & $\begin{array}{l}\text { Leaf extracts of Leucas } \\
\text { aspera and Hyptis } \\
\text { suaveolens }\end{array}$ & $4.02 / 11.22 \mathrm{mg} \cdot \mathrm{mL}^{-1}$ & $24 \mathrm{~h}$ & $\begin{array}{l}\text { Elumalai et al., } \\
2017\end{array}$ \\
\hline AgNP & $\begin{array}{l}\text { Ovicidal activity against } \\
\text { A. aegypti eggs }\end{array}$ & $\begin{array}{l}\text { Holarrhena } \\
\text { antidysenterica bark } \\
\text { extract }\end{array}$ & 5.53/12.01 ppm & $72 \mathrm{~h}$ & Kumar et al., 2018 \\
\hline ZnONP & $\begin{array}{l}\text { Larvicidal and ovicidal } \\
\text { activities against Aedes } \\
\text { aegypti }\end{array}$ & $\begin{array}{l}\text { Scadoxus multiflorus } \\
\text { leaf powder aqueous } \\
\text { extract }\end{array}$ & 34.04/78.06 ppm & $24 \mathrm{~h}$ & $\begin{array}{l}\text { Al-Dhabi and } \\
\text { Valan Arasu, } 2018\end{array}$ \\
\hline ZnONP & $\begin{array}{l}\text { Larvicidal activity } \\
\text { against of Aedes } \\
\text { aegypti (4th instar) }\end{array}$ & $\begin{array}{l}\text { Extract of the seaweed } \\
\text { Ulva lactuca }\end{array}$ & $22.38 / 41.94 \mu \mathrm{g} \cdot \mathrm{mL}^{-1}$ & $24 \mathrm{~h}$ & $\begin{array}{l}\text { Ishwarya et al., } \\
2018\end{array}$ \\
\hline ZnONP & $\begin{array}{l}\text { Larvicidal activity } \\
\text { against fourth instar of } \\
\text { Aedes aegypti }\end{array}$ & $\begin{array}{l}\text { Pedalium murex seed } \\
\text { extract }\end{array}$ & $34.88 / 64.56 \mu \mathrm{g} \cdot \mathrm{mL}^{-1}$ & $24 \mathrm{~h}$ & $\begin{array}{l}\text { Ishwarya et al., } \\
2017\end{array}$ \\
\hline AgNP & $\begin{array}{l}\text { Larvicidal property } \\
\text { against Anopheles } \\
\text { stephen and A. aegypti }\end{array}$ & $\begin{array}{l}\text { Belosynapsi Kewensis } \\
\text { leaf extract }\end{array}$ & 84.2/117.3 ppm & $24 \mathrm{~h}$ & $\begin{array}{l}\text { Bhuvaneswari } \\
\text { et al., } 2016\end{array}$ \\
\hline AgNP & $\begin{array}{l}\text { Potential larvicidal } \\
\text { activity against larvae of } \\
\text { Aedes aegypti (3rd } \\
\text { instar), Anopheles } \\
\text { stephensi, and Culex } \\
\text { quinquefasciatus }\end{array}$ & $\begin{array}{l}\text { Aqueous leaf extract of } \\
\text { Heliotropium indicum }\end{array}$ & $72.72 / 126.86 \mu \mathrm{g} \cdot \mathrm{mL}^{-1}$ & $24 \mathrm{~h}$ & $\begin{array}{l}\text { Veerakumar et al., } \\
2014\end{array}$ \\
\hline AgNP & $\begin{array}{l}\text { Larvicidal activity } \\
\text { against third and larvae } \\
\text { of Aedes aegypti (4th } \\
\text { instar) }\end{array}$ & $\begin{array}{l}\text { Leaf extract of Derris } \\
\text { trifoliata }\end{array}$ & $\begin{array}{l}\text { 3rd instar: } 7.0 / 17.76 \\
\text { mg.mL }{ }^{-1} \\
\text { 4th instar: } \\
5.87 / 12.11 \mathrm{mg} \cdot \mathrm{mL}^{-1}\end{array}$ & $24 h$ & Kumar et al., 2017 \\
\hline AgNP & $\begin{array}{l}\text { Larvicidal activity } \\
\text { against } 1 \text { st-4th instar } \\
\text { larvae dengue vector }\end{array}$ & $\begin{array}{l}3,5 \text { di-t-butyl- } 4 \\
\text { hidroxyanisole isolated } \\
\text { from Cynodon dactylon } \\
\text { leaf }\end{array}$ & $\begin{array}{l}\text { 1st-4th instar: } 2.5 ; \\
\text { 2.78; 3.02; 3.05/8.28; } \\
7.47 ; 8.13 ; 8.74 \mu \text { g.mL }^{-1}\end{array}$ & $24 h$ & $\begin{array}{l}\text { Ramanibai and } \\
\text { Velayutham, } 2016\end{array}$ \\
\hline AgNP & $\begin{array}{l}\text { Larvicidal and pupicidal } \\
\text { against Aedes aegypti } \\
\text { and Anopheles } \\
\text { stephensi }\end{array}$ & $\begin{array}{l}\text { Aqueous leaf filtrate } \\
\text { from Artemisia nilagirica }\end{array}$ & $\begin{array}{l}\text { 1st-4th instar: } 0.46 \text {; } \\
0.35 ; 0.33 ; 0.21 \% \\
\text { Pupa: 0.16\% } \\
\text { LC }_{90}: \text { N/A }\end{array}$ & $24 \mathrm{~h}$ & Nalini et al., 2017 \\
\hline
\end{tabular}

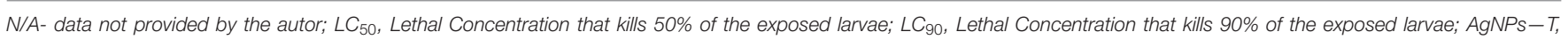
prepared by heating; AgNPs-RT, prepared by non-heating.

in order to determine regulatory framework will be used. Three main challenges should be addressed by FDA to boost the market of nano-based formulations: (i) development of a regulatory framework specific to nanomaterials; (ii) development of methods capable of characterize and quantify the toxicological impacts of nanomaterials, and (iii) deal with public acceptance and understanding through awareness programs and product labeling (Hua et al., 2018; Jones et al., 2019).
Also, economic issues can limiting the broad commercialization of nano-based formulations (Ventola, 2017; Jones et al., 2019). In comparison to conventional therapies, the production of a nano-based formulations required higher initial investments that will only be worth it from a business perspective if brings good opportunities for the pharmaceutical company, justifying their investment of R\&D sector and reduce substantially health care costs (Benelli et al., 2017; Hua et al., 2018). Future research should explore the possibility of (i) 
determine the mechanism of action of nano-based formulations; (ii) understand the behavior and interaction of nanomaterial in complex biological matrix, such as human body; (iii) evaluate the possible toxicity and residual effects of nanomaterials in both target and non-target organisms; (iv) development of a international legislation; (v) create a standard definition of nanotechnology and nanomaterials, and (vi) standardized methods for establishing the risk-benefit of nanomaterials, in order to create large scale production of nanodevices to fight against of arboviruses as suggested in literature (Parisi et al., 2015; Kah et al., 2018a,b).

As conclusion, as indicated in this review, it is important to learn and appreciate the great potential offered by nanotechnology in relation to the development of new and more efficient tools and products. In this regard, it is extremely important that ongoing research involves all sectors: academia, industries, research centers, and government agencies, in order to turning this technology into a sustainable commercial reality and

\section{REFERENCES}

Afsahi, S., Lerner, M. B., Goldstein, J. M., Lee, J., Tang, X., Bagarozzi, D. A., et al. (2018). Novel graphene-based biosensor for early detection of Zika virus infection. Biosens. Bioelectron. 100, 85-88. doi: 10.1016/j.bios.2017.08.051

Agnihotri, A., Wazed Ali, S., Das, A., and Alagirusamy, R. (2019). "11 - Insectrepellent textiles using green and sustainable approaches," in The Impact and Prospects of Green Chemistry for Textile Technology The Textile Institute Book Series, eds S. Islam and B. S. Butola (Woodhead Publishing), 307-325. doi: 10.1016/B978-0-08-102491-1.00011-3

Ahmed, T., Hyder, M. Z., Liaqat, I., and Scholz, M. (2019). Climatic conditions: conventional and nanotechnology-based methods for the control of mosquito vectors causing human health issues. Int. J. Environ. Res. Public Health 16:3165. doi: 10.3390/ijerph16173165

Akahata, W., and Ueno, R. (2017). Zika Virus Virus Like Particle. Available online at: https://patents.google.com/patent/WO2017150683A1/en (accessed November 14, 2018).

Al-Dhabi, N. A., and Valan Arasu, M. (2018). Environmentally-friendly green approach for the production of zinc oxide nanoparticles and their anti-fungal, ovicidal, and larvicidal properties. Nanomaterials 8:500. doi: 10.3390/nano8070500

Alharbi, N. S., Govindarajan, M., Kadaikunnan, S., Khaled, J. M., Almanaa, T. N., Alyahya, S. A., et al. (2018). Nanosilver crystals capped with Bauhinia acuminata phytochemicals as new antimicrobials and mosquito larvicides. J. Trace Elem. Med. Biol. 50, 146-153. doi: 10.1016/j.jtemb.2018. 06.016

Ali, Z. A., Roslan, M. A., Yahya, R., Wan Sulaiman, W. Y., and Puteh, R. (2017). Eco-friendly synthesis of silver nanoparticles and its larvicidal property against fourth instar larvae of Aedes aegypti. IET Nanobiotechnol. 11, 152-156. doi: 10.1049/iet-nbt.2015.0123

Ariffin, S. A. B., Adam, T., Hashim, U., Faridah Sfaridah, S., Zamri, I., and Uda, M. N. A. (2013). Plant diseases detection using nanowire as biosensor transducer. Adv. Mat. Res. 832, 113-117. doi: 10.4028/www.scientific.net/AMR.832.113

Awad, M. A. G., Hendi, A. A., Wagealla, M. A. E., Ortashi, K. M. O., and Virk, P. (2016). Synthesis of Nanoparticles of Metals and Metal Oxides Using Plant Seed Extract. Available online at: https://patents.google.com/patent/US9428399B1/ en?q=green $\$+\$$ sinthesis $\& \mathrm{q}=\% 22$ silver $\$+\$$ nanoparticle $\% 22 \&$ oq $=$ green $\$+$

\$sinthesis\$++\$\%22silver\$+\$nanoparticle\%22\$+\$ (accessed October 18, 2018).

Aytur, T., Foley, J., Anwar, M., Boser, B., Harris, E., and Beatty, P. R. (2006). A novel magnetic bead bioassay platform using a microchip-based sensor for infectious disease diagnosis. J. Immunol. Methods 314, 21-29. doi: 10.1016/j.jim.2006.05.006 to create alternatives for detection and control of Aedes aegypti-borne diseases.

\section{AUTHOR CONTRIBUTIONS}

EC, JO, and LF proposed the structure of the manuscript. EC, JO, DA, CR, CB, VM, and RM wrote the manuscript. EC and LF revised the manuscript. All authors read and approved the final version of the manuscript.

\section{ACKNOWLEDGMENTS}

The authors are grateful for financial support provided by MCTIC-CNPq/MEC-CAPES/MS-Decit/FNDCT N N $^{\circ}$ 14/2016Prevenção e Combate ao vírus Zika-Processo CNPq: 440350/2016-6 e Processo CAPES: 88881.130834/2016-01. The authors thank the São Paulo State Research Foundation (FAPESP) for scholarships awarded to EC (\#2017/24402-1), DA (\#2018/14743-0), and CR (2018/02404-5).

Baeumner, A. J., Kwakye, S. D. S., Goral, V. N., and Zaytseva, N. V. (2005) Microfluidic Biosensor and Methods of Use. Available online at: https://patents. google.com/patent/WO2005084404A2/en?oq=WO2005084404A2 (accessed November 14, 2018).

Balaji, A. P. B., Ashu, A., Manigandan, S., Sastry, T. P., Mukherjee, A., and Chandrasekaran, N. (2017). Polymeric nanoencapsulation of insect repellent: Evaluation of its bioefficacy on Culex quinquefasciatus mosquito population and effective impregnation onto cotton fabrics for insect repellent clothing. J. King Saud University 29, 517-527. doi: 10.1016/j.jksus.2016.12.005

Balasubramani, S., Rajendhiran, T., Moola, A. K., and Diana, R. K. B. (2017). Development of nanoemulsion from Vitex negundo L. essential oil and their efficacy of antioxidant, antimicrobial and larvicidal activities (Aedes aegypti L.). Environ. Sci. Pollution Res. 24, 15125-15133. doi: 10.1007/s11356-017-9118-y

Barradas, T., Perdiz Senna, J., Ricci Júnior, E., and Regina Elias Mansur, C. (2016). Polymer-based drug delivery systems applied to insects repellents devices: a review. Curr. Drug Deliv. 13, 221-235. doi: 10.2174/1567201813666151207110515

Barrett, T. W., Gautam, S., Mitra, R., and Thorne, J. (2018). Nano-Field Electrical Sensor. U.S. Patent No 20180067107A1. Available online at: https:/patents.google.com/patent/US20180067107A1/en?q=Nano-field\&q= electrical\&q=Sensor\&q=Biomarkes\&q=targets\&q=analytes\&q=determining\& $\mathrm{q}=$ impedance $\& \mathrm{q}=$ bodily+fluid $\& \mathrm{q}=$ nanoporous + membrane\&oq=Nanofield+electrical+Sensor+for+Biomarkes+and+other+targets+analytes+by+ determining+impedance+in+bodily+fluid+on+nanoporous+membrane (accessed February 12, 2020).

Basso, C. R., Tozato, C. C., Crulhas, B. P., Castro, G. R., Junior, J. P. A., and Pedrosa, V. A. (2018). An easy way to detect dengue virus using nanoparticle-antibody conjugates. Virology 513, 85-90. doi: 10.1016/j.virol.2017.10.001

Batool, K., Alam, I., Wu, S., Liu, W., Zhao, G., Chen, M., et al. (2018). Transcriptomic analysis of aedes aegypti in response to mosquitocidal Bacillus thuringiensis LLP29 toxin. Sci. Rep. 8:12650. doi: 10.1038/s41598-018-30741-x

Beech, R., WHITE, E., and Katchman, B. (2018). Biosensor Disease and Infection Screening. Available online at: https://patents.google.com/patent/ WO2018026931A1/en?oq=WO2018026931A1 (accessed November 14, 2018).

Benelli, G. (2016). Plant-mediated biosynthesis of nanoparticles as an emerging tool against mosquitoes of medical and veterinary importance: a review. Parasitol. Res. 115, 23-34. doi: 10.1007/s00436-015-4800-9

Benelli, G., Caselli, A., and Canale, A. (2017). Nanoparticles for mosquito control: challenges and constraints. J. King Saud Univers. 29, 424-435. doi: 10.1016/j.jksus.2016.08.006

Benelli, G., Jeffries, C. L., and Walker, T. (2016). Biological control of mosquito vectors: past, present, and future. Insects 7:52. doi: 10.3390/insects7040052 
Benelli, G., Maggi, F., Pavela, R., Murugan, K., Govindarajan, M., Vaseeharan, B., et al. (2018a). Mosquito control with green nanopesticides: towards the one health approach? A review of non-target effects. Environ. Sci. Pollut. Res. 25, 10184-10206.

Benelli, G., Maggi, F., Pavela, R., Murugan, K., Govindarajan, M., Vaseeharan, B., et al. (2018b). Mosquito control with green nanopesticides: towards the one health approach? A review of non-target effects. Environ. Sci. Pollut. Res. Int. 25, 10184-10206. doi: 10.1007/s11356-017-9752-4

Benelli, G., and Mehlhorn, H. (2016). Declining malaria, rising of dengue and Zika virus: insights for mosquito vector control. Parasitol. Res. 115, 1747-1754. doi: 10.1007/s00436-016-4971-z

Berini, P. S. J., and Wong, W. R. (2018). Long-Range Surface PlasmonPolariton Biosensor. Available online at: https://patents.google.com/patent/ WO2018090125A1/fr?oq=WO2018090125A1\$+\$Accessed\$+\$November \$+ $\$ 14 \% 2 c \$+\$ 2018$ (accessed January 15, 2020).

Bhuvaneswari, R., Xavier, R. J., and Arumugam, M. (2016). Larvicidal property of green synthesized silver nanoparticles against vector mosquitoes (Anopheles stephensi and Aedes aegypti). J. King Saud Univers. Sci. 28, 318-323. doi: $10.1016 /$ j.jksus.2015.10.006

Bosak, A., Saraf, N., Willenberg, A., Kwan, M. W. C., Alto, B. W., Jackson, G. W., et al. (2019). Aptamer-gold nanoparticle conjugates for the colorimetric detection of arboviruses and vector mosquito species. RSC Adv. 9, 2375223763. doi: 10.1039/C9RA02089F

Braga, L., Marini, B., and Ippodrino, R. (2015). Biosensors for the Detection of Infection and Associated Maladies. Available online at: https://patents.google. com/patent/WO2015114506A3/en (accessed November 14, 2018).

Brister, M., Neale, P. V., Saint, S., Petisce, J. R., McGee, T. F., Codd, D. S., et al. (2012). Transcutaneous Analyte Sensor. Available online at: https://patents. google.com/patent/US8229534B2/en (accessed November 14, 2018).

Cabarcos, E. J. L., González, D. M., Laurenti, M., Cristóbal, P. A., and Retama, J. R. (2017). Biosensor for the Detection of Nucleic Acids, Preparation Method and Use. Available online at: https://patents.google.com/patent/ES2580138A1/ en (accessed November 14, 2018).

Carrell, C., Kava, A., Nguyen, M., Menger, R., Munshi, Z., Call, Z., et al. (2019). Beyond the lateral flow assay: a review of paper-based microfluidics. Microelectron. Eng. 206, 45-54. doi: 10.1016/j.mee.2018.12.002

Cecchetto, J., Fernandes, F. C. B., Lopes, R., and Bueno, P. R. (2017). The capacitive sensing of NS1 Flavivirus biomarker. Biosens. Bioelectron. 87, 949-956. doi: 10.1016/j.bios.2016.08.097

Dias, A. C. M. S., Gomes-Filho, S. L. R., Silva, M. M. S., and Dutra, R. F. (2013). A sensor tip based on carbon nanotube-ink printed electrode for the dengue virus NS1 protein. Biosens. Bioelectron. 44, 216-221. doi: 10.1016/j.bios.2012. 12.033

Dinda, S. C. (2018). "Bioaccumulation and toxic profiling of nanostructured particles and materials," in Unraveling the Safety Profile of Nanoscale Particles and Materials - From Biomedical to Environmental Applications, eds A. F. de Castro Gomes (University of Minho). doi: 10.5772/intechopen. 74802

Durán, N., Islan, G. A., Durán, M., and Castro, G. R. (2016). Nanobiotechnology Solutions against Aedes aegypti. J. Braz. Chem. Soc. 27, 1139-1149. doi: 10.5935/0103-5053.20160122

Eboigbodin, K. E., Brummer, M., Ojalehto, T., and Hoser, M. (2016). Rapid molecular diagnostic test for Zika virus with low demands on sample preparation and instrumentation. Diagn. Microbiol. Infect. Dis. 86, 369-371. doi: 10.1016/j.diagmicrobio.2016.08.027

Elumalai, D., Hemavathi, M., Deepaa, C. V., and Kaleena, P. K. (2017). Evaluation of phytosynthesised silver nanoparticles from leaf extracts of Leucas aspera and Hyptis suaveolens and their larvicidal activity against malaria, dengue and filariasis vectors. Parasite Epidemiol. Control 2, 15-26. doi: 10.1016/j.parepi.2017.09.001

Eyupoglu, S., Kut, D., Girisgin, A. O., Eyupoglu, C., Ozuicli, M., Dayioglu, H., et al. (2018). Investigation of the bee-repellent properties of cotton fabrics treated with microencapsulated essential oils. Textile Res. J. 89, 1417-1435. doi: 10.1177/0040517518773370

Ferreira, T. P., Haddi, K., Corrêa, R. F. T., Zapata, V. L. B., Piau, T. B., Souza, L. F. N., et al. (2019). Prolonged mosquitocidal activity of Siparuna guianensis essential oil encapsulated in chitosan nanoparticles. PLoS Negl. Trop. Dis. 13:e0007624. doi: 10.1371/journal.pntd.0007624
Fletcher, S. J., and Milligan, A. S. (2009). Auto-Feedback Loop Biosensor Available online at: https://patents.google.com/patent/WO2009152566A1/en? oq=WO2009152566A1 (accessed November 14, 2018).

Forgearini, J. C., Michalowski, C. B., Assumpção, E., Pohlmann, A. R., and Guterres, S. S. (2016). Development of an insect repellent spray for textile based on permethrin-loaded lipid-core nanocapsules. J. Nanosci. Nanotechnol. 16, 1301-1309. doi: 10.1166/jnn.2016.11665

Fraceto, L. F., Barbosa, M. C. M., Oliveira, J. L., and Campos, E. V. R. (2018). Sistemas Nanoestruturados E Seu Uso. Available online at: https://patents. google.com/patent/WO2017143421A1/pt?oq=repelentes+aedes+aegypti (accessed February 12, 2020).

Galvão, J. G., Cerpe, P., Santos, D. A., Gonsalves, J. K., Santos, A. J., Nunes, R. K., et al. (2018). Lippia gracilis essential oil in $\beta$-cyclodextrin inclusion complexes: an environmentally safe formulation to control Aedes aegypti larvae: Lippia gracilis essential oil in $\beta$-cyclodextrin inclusion complexes. Pest Manag. Sci. 75, 452-459. doi: 10.1002/ps.5138

García, A. A., Franco, L. S., Pirez-Gomez, M. A., Pech-Pacheco, J. L., MendezGalvan, J. F., Machain-Williams, C., et al. (2017). Feasibility study of an optical caustic plasmonic light scattering sensor for human serum anti-dengue protein E antibody detection. Diagnostics 7:47. doi: 10.3390/diagnostics7030047

Gomes, G. M., Bigon, J. P., Montoro, F. E., and Lona, L. M. F. (2018). Encapsulation of $N, N$-diethyl- meta -toluamide (DEET) via miniemulsion polymerization for temperature controlled release: encapsulation of $N, N$-diethyl- meta -toluamide (DEET) via miniemulsion polymerization for temperature controlled release. J. Appl. Polym. Sci. 139:47139. doi: 10.1002/app.47139

Govindarajan, M., Vijayan, P., Kadaikunnan, S., Alharbi, N. S., and Benelli, G. (2016). One-pot biogenic fabrication of silver nanocrystals using Quisqualis indica: effectiveness on malaria and Zika virus mosquito vectors, and impact on non-target aquatic organisms. J. Photochem. Photobiol. Biol. 162, 646-655. doi: 10.1016/j.jphotobiol.2016.07.036

Hameed, A., Fatima, G. R., Malik, K., Muqadas, A., and Fazal-ur-Rehman, M. (2019). Scope of nanotechnology in cosmetics: dermatology and skin care products. J. Med. Chem. Sci. 2, 9-16. doi: 10.26655/jmchemsci.2019.6.2

Hao, J., Yang, M., Tsang, M.-K., and Ye, W. (2018). Heterogeneous Microarray Based Hybrid Upconversion Nanoprobe/Nanoporous Membrane System. U.S Patent No 20180246084. Available online at: https://patents.google.com/patent/ US20180246084A1/en?oq=US20180246084+-+Heterogeneous+microarray+ based+hybrid+upconversion+nanoprobe $\% 2$ fnanoporous+membrane+system (accessed February 12, 2020).

Hoag, G. E., Collins, J. B., Varma, R. S., and Nadagouda, M. N. (2011). Green Synthesis of Nanometals Using Plant Extracts and Use Thereof. Available online at: https://patents.google.com/patent/US8057682B2/en?q=green $\$+\$$ sinthesis\& $\mathrm{q}=\% 22$ silver $\$+\$$ nanoparticle $\% 22 \&$ oq $=$ green $\$+\$$ sinthesis $\$++\$ \% 22$ silver $\$+$ \$nanoparticle\%22\$+\$ (accessed October 18, 2018).

Hua, S., de Matos, M. B. C., Metselaar, J. M., and Storm, G. (2018). Current trends and challenges in the clinical translation of nanoparticulate nanomedicines: pathways for translational development and commercialization. Front. Pharmacol. 9:14. doi: 10.3389/fphar.2018.00790

Huang, S., Li, C., Lin, B., and Qin, J. (2010). Microvalve and micropump controlled shuttle flow microfluidic device for rapid DNA hybridization. Lab Chip 10, 2925-2931. doi: 10.1039/c005227b

Ishwarya, R., Vaseeharan, B., Anuradha, R., Rekha, R., Govindarajan, M., Alharbi, N. S., et al. (2017). Eco-friendly fabrication of Ag nanostructures using the seed extract of Pedalium murex, an ancient Indian medicinal plant: histopathological effects on the Zika virus vector Aedes aegypti and inhibition of biofilm-forming pathogenic bacteria. J. Photochem. Photobiol. B Biol. 174, 133-143. doi: 10.1016/j.jphotobiol.2017.07.026

Ishwarya, R., Vaseeharan, B., Kalyani, S., Banumathi, B., Govindarajan, M., Alharbi, N. S., et al. (2018). Facile green synthesis of zinc oxide nanoparticles using Ulva lactuca seaweed extract and evaluation of their photocatalytic, antibiofilm and insecticidal activity. J. Photochem. Photobiol. Biol. 178, 249-258. doi: 10.1016/j.jphotobiol.2017.11.006

Iswardy, E., Tsai, T.-C., Cheng, I.-F., Ho, T.-C., Perng, G. C., and Chang, H.-C. (2017). A bead-based immunofluorescence-assay on a microfluidic dielectrophoresis platform for rapid dengue virus detection. Biosens. Bioelectron. 95, 174-180. doi: 10.1016/j.bios.2017.04.011

Jeevanandam, J., Barhoum, A., Chan, Y. S., Dufresne, A., and Danquah, M. K. (2018). Review on nanoparticles and nanostructured materials: history, 
sources, toxicity and regulations. Beilstein J. Nanotechnol. 9, 1050-1074. doi: 10.3762/bjnano.9.98

Jones, A. A. D., Mi, G., and Webster, T. J. (2019). A status report on FDA approval of medical devices containing nanostructured materials. Trends Biotechnol. 37, 117-120. doi: 10.1016/j.tibtech.2018.06.003

Kadam, S. L., Yadav, P., Bhutkar, S., Patil, V. D., Shukla, P. G., and Shanmuganathan, K. (2019). Sustained release insect repellent microcapsules using modified cellulose nanofibers (mCNF) as pickering emulsifier. Colloids Surfaces A. 582:123883. doi: 10.1016/j.colsurfa.2019.123883

Kah, M., Kookana, R. S., Gogos, A., and Bucheli, T. D. (2018a). A critical evaluation of nanopesticides and nanofertilizers against their conventional analogues. Nat. Nanotech 13, 677-684. doi: 10.1038/s41565-018-0131-1

Kah, M., Walch, H., and Hofmann, T. (2018b). Environmental fate of nanopesticides: durability, sorption and photodegradation of nanoformulated clothianidin. Environ. Sci. 5, 882-889. doi: 10.1039/C8EN00038G

Kaushik, A., and Nair, M. (2018). Rapid Zika Virus Detection Using Nano-Enabled Electrochemical Sensing System. Available online at: https://patents.google.com/ patent/US20180059099A1/en (accessed November 14, 2018).

Khater, H. F., Selim, A. M., Abouelella, G. A., Abouelella, N. A., Murugan, K., Vaz, N. P., et al. (2019). "Commercial mosquito repellents and their safety concerns," in Malaria, eds F. H. Kasenga (Malawi Adventist University). doi: $10.5772 /$ intechopen. 87436

Koczula, K. M., and Gallotta, A. (2016). Lateral flow assays. Essays Biochem. 60, 111-120. doi: 10.1042/EBC20150012

Kumar, D., Kumar, G., and Agrawal, V. (2018). Green synthesis of silver nanoparticles using Holarrhena antidysenterica (L.) Wall.bark extract and their larvicidal activity against dengue and filariasis vectors. Parasitol. Res. 117, 377-389. doi: 10.1007/s00436-017-5711-8

Kumar, S., Lather, V., and Pandita, D. (2015). Green synthesis of therapeutic nanoparticles: an expanding horizon. Nanomedicine 10, 2451-2471. doi: $10.2217 / \mathrm{nnm} .15 .112$

Kumar, V. A., Ammani, K., Jobina, R., Subhaswaraj, P., and Siddhardha, B. (2017). Photo-induced and phytomediated synthesis of silver nanoparticles using Derris trifoliata leaf extract and its larvicidal activity against Aedes aegypti. J. Photochem. Photobiol. B Biol. 171, 1-8. doi: 10.1016/j.jphotobiol.2017.04.022

Laury-Kleintop, L., and Rutner, H. (2015). Biocoated Piezoelectric Biosensor Platform for Point-Of-Care Diagnostic Use. Available online at: https://patents. google.com/patent/US20150111765A1/en?oq=US20150111765A1 (accessed November 14, 2018).

Laux, P., Tentschert, J., Riebeling, C., Braeuning, A., Creutzenberg, O., Epp, A., et al. (2018). Nanomaterials: certain aspects of application, risk assessment and risk communication. Arch. Toxicol. 92, 121-141. doi: $10.1007 / \mathrm{s} 00204-017-2144-1$

Li, J., Yang, K., Wu, Z., Li, X., and Duan, Q. (2019). Nitrogen-doped porous carbon-based fluorescence sensor for the detection of ZIKV RNA sequences: fluorescence image analysis. Talanta 205:120091. doi: 10.1016/j.talanta.2019.06.091

Liu, S., Liu, L., Tan, X., and Meng, B. (2013). Environmentally-Friendly Synthetic Method for Metal Nanoparticle. Available online at: https://patents.google.com/ patent/CN103071808A/en?q=green\&q=synthesis\&q=nanoparticle\&oq $\$=+$ \$green\$+\$synthesis\$+\$nanoparticle (accessed October 18, 2018).

Lucia, A., Toloza, A. C., Guzmán, E., Ortega, F., and Rubio, R. G. (2017). Novel polymeric micelles for insect pest control: encapsulation of essential oil monoterpenes inside a triblock copolymer shell for head lice control. PeerJ 5:e3171. doi: 10.7717/peerj.3171

Magro, M., Bramuzzo, S., Baratella, D., Ugolotti, J., Zoppellaro, G., Chemello, G., et al. (2019). Self-assembly of chlorin-e6 on $\gamma$-Fe2O3 nanoparticles: application for larvicidal activity against Aedes aegypti. J. Photochem. Photobiol. 194, 21-31. doi: $10.1016 /$ j.jphotobiol.2019.03.004

Marinero-Caceres, E. E., Kuhn, R. J., Stanciu, L. A., and Jin, S.-A. (2017). Functionalized Particles for Label-Free DNA Impedimetric Biosensor for $D N A$ and RNA Sensing. Available online at: https://patents.google.com/ patent/US20170107565A1/en?oq=US\$+\$2017\%2f0107565\$+\$A1 (accessed November 14, 2018).

Mazlan, N.-F., Tan, L. L., Karim, N. H. A., Heng, L. Y., Jamaluddin, N. D., Yusof, N. Y. M., et al. (2019). Acrylic-based genosensor utilizing metal salphen labeling approach for reflectometric dengue virus detection. Talanta 198, 358-370. doi: 10.1016/j.talanta.2019.02.036
Misni, N., Nor, Z. M., and Ahmad, R. (2017). Repellent effect of microencapsulated essential oil in lotion formulation against mosquito bites. J. Vector Borne Dis. $54,44-53$.

Muñoz, V., Buffa, F., Molinari, F., Hermida, L. G., García, J. J., and Abraham, G. A. (2019). Electrospun ethylcellulose-based nanofibrous mats with insect-repellent activity. Mater. Lett. 253, 289-292. doi: 10.1016/j.matlet.2019.06.091

Murugan, K., Dinesh, D., Paulpandi, M., Althbyani, A. D. M., Subramaniam, J., Madhiyazhagan, P., et al. (2015). Nanoparticles in the fight against mosquito-borne diseases: bioactivity of Bruguiera cylindrica-synthesized nanoparticles against dengue virus DEN-2 (in vitro) and its mosquito vector Aedes aegypti (Diptera: Culicidae). Parasitol. Res. 114, 4349-4361. doi: 10.1007/s00436-015-4676-8

Nakata, Y., and Röst, G. (2015). Global analysis for spread of infectious diseases via transportation networks. J. Math. Biol. 70, 1411-1456. doi: $10.1007 / \mathrm{s} 00285-014-0801-\mathrm{z}$

Nalini, M., Lena, M., Sumathi, P., and Sundaravadivelan, C. (2017). Effect of phytosynthesized silver nanoparticles on developmental stages of malaria vector, Anopheles stephensi and dengue vector, Aedes aegypti. Egyptian J. Basic Appl. Sci. 4, 212-218. doi: 10.1016/j.ejbas.2017.04.005

Nawaz, M. H., Hayat, A., Catanante, G., Latif, U., and Marty, J. L. (2018). Development of a portable and disposable NS1 based electrochemical immunosensor for early diagnosis of dengue virus. Anal. Chim. Acta 1026, 1-7. doi: 10.1016/j.aca.2018.04.032

Nicolini, A. M., McCracken, K. E., and Yoon, J.-Y. (2017a). Future developments in biosensors for field-ready Zika virus diagnostics. J. Biol. Eng. 11:7.

Nicolini, A. M., McCracken, K. E., and Yoon, J.-Y. (2017b). Future developments in biosensors for field-ready Zika virus diagnostics. J. Biol. Eng. 11:7. doi: 10.1186/s13036-016-0046-Z

Omar, N. A. S., Fen, Y. W., Abdullah, J., Chik, C. E. N., and Mahdi, M. A. (2018). Development of an optical sensor based on surface plasmon resonance phenomenon for diagnosis of dengue virus E-protein. Sens. Bio-Sensing Res. 20, 16-21. doi: 10.1016/j.sbsr.2018.06.001

Osanloo, M., Arish, J., and Sereshti, H. (2019). Developed methods for the preparation of electrospun nanofibers containing plant-derived oil or essential oil: a systematic review. Polym. Bull. doi: 10.1007/s00289-019-03042-0. [Epub ahead of print].

Parisi, C., Vigani, M., and Rodríguez-Cerezo, E. (2015). Agricultural nanotechnologies: what are the current possibilities? Nano Today 10, 124-127. doi: 10.1016/j.nantod.2014.09.009

Pashchenko, O., Shelby, T., Banerjee, T., and Santra, S. (2018). A comparison of optical, electrochemical, magnetic, and colorimetric point-of-care biosensors for infectious disease diagnosis. ACS Infect. Dis. 4, 1162-1178. doi: 10.1021/acsinfecdis.8b00023

Patterson, J., Sammon, M., and Garg, M. (2016). Dengue, Zika and Chikungunya: emerging arboviruses in the new world. West. J. Emerg. Med. 17, 671-679. doi: 10.5811/westjem.2016.9.30904

Paula, C. A. D., Dias, A. M. R., and Heffliger, R. A. (2017). Sistema Nanométrico De Liberação Prolongada De Ativos Cosméticos e/ou Repelentes. Available online at: https://patents.google.com/patent/WO2017143421A1/pt? oq=WO2017143421A1 (accessed November 14, 2018).

Pessoa, L. Z., da Duarte, J. L., Ferreira, R. M., dos Oliveira, A. E. M., Cruz, R. A. S. Faustino, S. M. M., et al. (2018). Nanosuspension of quercetin: preparation, characterization and effects against Aedes aegypti larvae. Revista Brasileira de Farmacog. 28, 618-625. doi: 10.1016/j.bjp.2018.07.003

Pinto, I. C., Cerqueira-Coutinho, C. S., Santos, E. P., Carmo, F. A., and RicciJunior, E. (2017). Development and characterization of repellent formulations based on nanostructured hydrogels. Drug Dev. Ind. Pharm. 43, 67-73. doi: 10.1080/03639045.2016.1220564

Priye, A., Bird, S. W., Light, Y. K., Ball, C. S., Negrete, O. A., and Meagher, R. J. (2017). A smartphone-based diagnostic platform for rapid detection of Zika, chikungunya, and dengue viruses. Sci. Rep. 7:44778. doi: 10.1038/srep44778

Ragavan, V. V., Roy, A., and Rutner, H. (2011). Integrated Microchip Sensor System for Detection of Infectious Agents. Available online at: https://patents. google.com/patent/US20110136262A1/en?oq=US\$+\$2011\%2f0136262\$+\$A1 (accessed November 14, 2018).

Ramanibai, R., and Velayutham, K. (2016). Synthesis of silver nanoparticles using 3,5-di-t-butyl-4-hydroxyanisole from Cynodon dactylon against Aedes 
aegypti and Culex quinquefasciatus. J. Asia Pac. Entomol. 19, 603-609. doi: 10.1016/j.aspen.2016.06.007

Ramar, M., Manonmani, P., Arumugam, P., Kannan, S. K., Erusan, R. R., and Murugan, K. (2017). Nano-insecticidal formulations from essential oil (Ocimum sanctum) and fabricated in filter paper on adult of Aedes aegypti and Culex quinquefasciatus. J. Entomol. Zool. Stud. 5, 1769-1774.

Rashid, J. I. A., and Yusof, N. A. (2018). Laboratory diagnosis and potential application of nucleic acid biosensor approach for early detection of dengue virus infections. Biosci. Biotechnol. Res. Asia 15, 245-255. doi: $10.13005 / \mathrm{bbra} / 2628$

Rong, Z., Wang, Q., Sun, N., Jia, X., Wang, K., Xiao, R., et al. (2019). Smartphonebased fluorescent lateral flow immunoassay platform for highly sensitive pointof-care detection of Zika virus nonstructural protein 1. Anal. Chim. Acta 1055, 140-147. doi: 10.1016/j.aca.2018.12.043

Roni, M., Murugan, K., Panneerselvam, C., Subramaniam, J., Nicoletti, M., Madhiyazhagan, P., et al. (2015). Characterization and biotoxicity of Hypnea musciformis-synthesized silver nanoparticles as potential eco-friendly control tool against Aedes aegypti and Plutella xylostella. Ecotoxicol. Environ. Saf. 121, 31-38. doi: 10.1016/j.ecoenv.2015.07.005

Sabalza, M., Yasmin, R., Barber, C. A., Castro, T., Malamud, D., Kim, B. J., et al. (2018). Detection of Zika virus using reverse-transcription LAMP coupled with reverse dot blot analysis in saliva. PLoS ONE 13:e192398. doi: 10.1371/journal.pone.0192398

Sajid, M., Ilyas, M., Basheer, C., Tariq, M., Daud, M., Baig, N., et al. (2015). Impact of nanoparticles on human and environment: review of toxicity factors, exposures, control strategies, and future prospects. Environ. Sci. Pollut Res. Int. 22, 4122-4143. doi: 10.1007/s11356-014-3994-1

Sánchez-Purrà, M., Carré-Camps, M., de Puig, H., Bosch, I., Gehrke, L., and Hamad-Schifferli, K. (2017). Surface-enhanced raman spectroscopy-based sandwich immunoassays for multiplexed detection of Zika and Dengue viral biomarkers. ACS Infect Dis. 3, 767-776. doi: 10.1021/acsinfecdis.7b00110

Schnell-Inderst, P., Hunger, T., Conrads-Frank, A., Arvandi, M., and Siebert, U. (2018). Recommendations for primary studies evaluating therapeutic medical devices were identified and systematically reported through reviewing existing guidance. J. Clin. Epidemiol. 94, 46-58. doi: 10.1016/j.jclinepi.2017.10.007

Sethi, R. S. (1994). Transducer aspects of biosensors. Biosens. Bioelectr. 9, 243-264. doi: 10.1016/0956-5663(94)80127-4

Sharma, D. H. K. (2019). Formulation and evaluation of controlled release herbal mosquito repellent gel containing encapsulated essential oils obtained from natural sources indigenous to Northeast India. Asian J. Pharmaceut. 13. doi: $10.22377 /$ ajp.v13i01.3005

Silva, L. S., Mar, J. M., Azevedo, S. G., Rabelo, M. S., Bezerra, J. A., Campelo, P. H., et al. (2019). Encapsulation of Piper aduncum and Piper hispidinervum essential oils in gelatin nanoparticles: a possible sustainable control tool of Aedes aegypti, Tetranychus urticae and Cerataphis lataniae. J. Sci. Food Agric. 99, 685-695. doi: 10.1002/jsfa.9233

Singhal, C., Dubey, A., Mathur, A., Pundir, C. S., and Narang, J. (2018). Paper based DNA biosensor for detection of chikungunya virus using gold shells coated magnetic nanocubes. Proc. Biochem. 74, 35-42. doi: 10.1016/j.procbio.2018.08.020

Sintubin, L., Verstraete, W., and Boon, N. (2012). Biologically produced nanosilver: current state and future perspectives. Biotechnol. Bioeng. 109, 2422-2436. doi: 10.1002/bit.24570

Soares, S., Sousa, J., Pais, A., and Vitorino, C. (2018). Nanomedicine: principles, properties, and regulatory issues. Front. Chem. 6:360. doi: $10.3389 /$ fchem. 2018.00360

Song, J., Mauk, M. G., Hackett, B. A., Cherry, S., Bau, H. H., and Liu, C. (2016). Instrument-free point-of-care molecular detection of zika virus. Anal. Chem. 88, 7289-7294. doi: 10.1021/acs.analchem.6b01632

Soutschek, E., Boecher, O., and Noelting, C. (2019). Method for the Immunological Diagnosis of a Sample with a Potential Infection with an Arbovirus and Test Kits Suitable for This Purpose. U.S. Patent No 20190227065. Available online at: http://www.freepatentsonline.com/y2019/0227065.html (accessed February 12, 2020).

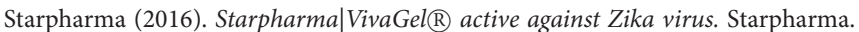
Available online at: https://www.starpharma.com/news/281 (accessed December 31, 2019).
Suganya, P., Vaseeharan, B., Vijayakumar, S., Balan, B., Govindarajan, M., Alharbi, N. S., et al. (2017). Biopolymer zein-coated gold nanoparticles: synthesis, antibacterial potential, toxicity and histopathological effects against the Zika virus vector Aedes aegypti. J. Photochem. Photobiol. 173, 404-411. doi: 10.1016/j.jphotobiol.2017.06.004

Tancharoen, C., Sukjee, W., Thepparit, C., Jaimipuk, T., Auewarakul, P., Thitithanyanont, A., et al. (2019). Electrochemical biosensor based on surface imprinting for Zika virus detection in serum. ACS Sens. 4, 69-75. doi: 10.1021/acssensors.8b00885

Tavares, M., da Silva, M. R. M., de Oliveira de Siqueira, L. B., Rodrigues, R. A. S., Bodjolle-d'Almeida, L., dos Santos, E. P., et al. (2018). Trends in insect repellent formulations: a review. Int. J. Pharm. 539, 190-209. doi: 10.1016/j.jpharm.2018.01.046

Thanh, B. T., Van Sau, N., Ju, H., Bashir, M. J. K., Jun, H. K., Phan, T. B., et al. (2019). Immobilization of protein a on monodisperse magnetic nanoparticles for biomedical applications. J. Nanomater. 2019:2182471. doi: $10.1155 / 2019 / 2182471$

Theillet, G., Rubens, A., Foucault, F., Dalbon, P., Rozand, C., Leparc-Goffart, I., et al. (2018). Laser-cut paper-based device for the detection of dengue nonstructural NS1 protein and specific IgM in human samples. Arch. Virol. 163, 1757-1767. doi: 10.1007/s00705-018-3776-z

Thomas, J. (2019). Anti-Parasitic Compositions and Methods. Available online at: https://patents.google.com/patent/US20190160016A1/en (accessed January 6, 2020).

Tian, B., Qiu, Z., Ma, J., Zardán Gómez de la Torre, T., Johansson, C., Svedlindh, P., et al. (2016). Attomolar Zika virus oligonucleotide detection based on loopmediated isothermal amplification and AC susceptometry. Biosens. Bioelectron. 86, 420-425. doi: 10.1016/j.bios.2016.06.085

Tripathy, S., Krishna Vanjari, S. R., Singh, V., Swaminathan, S., and Singh, S. G. (2017). Electrospun manganese (III) oxide nanofiber based electrochemical DNA-nanobiosensor for zeptomolar detection of dengue consensus primer. Biosens. Bioelectr. 90, 378-387. doi: 10.1016/j.bios.2016.12.008

Udayabhanu, J., Kannan, V., Tiwari, M., Natesan, G., Giovanni, B., and Perumal, V. (2018). Nanotitania crystals induced efficient photocatalytic color degradation, antimicrobial and larvicidal activity. J. Photochem. Photobiol. B Biol. 178, 496-504. doi: 10.1016/j.jphotobiol.2017.12.005

Veerakumar, K., Govindarajan, M., Rajeswary, M., and Muthukumaran, U. (2014). Mosquito larvicidal properties of silver nanoparticles synthesized using Heliotropium indicum (Boraginaceae) against Aedes aegypti, Anopheles stephensi, and Culex quinquefasciatus (Diptera: Culicidae). Parasitol. Res. 113, 2363-2373. doi: 10.1007/s00436-014-3895-8

Ventola, C. L. (2017). Progress in nanomedicine: approved and investigational nanodrugs. $P$ T 42, 742-755.

Vinayagam, S., Rajaiah, P., Mukherjee, A., and Natarajan, C. (2018). DNAtriangular silver nanoparticles nanoprobe for the detection of dengue virus distinguishing serotype. Spectrochim. Acta A Mol. Biomol. Spectrosc. 202, 346-351. doi: 10.1016/j.saa.2018.05.047

Vo-Dinh, T. (2004). Multifunctional and Multispectral Biosensor Devices and Methods of Use. Available online at: https://patents.google.com/patent/ US6743581B1/en (accessed November 14, 2018).

Wasik, D., Mulchandani, A., and Yates, M. V. (2017). A heparin-functionalized carbon nanotube-based affinity biosensor for dengue virus. Biosens. Bioelectron. 91, 811-816. doi: 10.1016/j.bios.2017.01.017

Werdin González, J. O., Jesser, E. N., Yeguerman, C. A., Ferrero, A. A., and Fernández Band, B. (2017). Polymer nanoparticles containing essential oils: new options for mosquito control. Environ. Sci. Pollut. Res. 24, 17006-17015. doi: 10.1007/s11356-017-9327-4

Wilder-Smith, A., Gubler, D. J., Weaver, S. C., Monath, T. P., Heymann, D. L., and Scott, T. W. (2017). Epidemic arboviral diseases: priorities for research and public health. Lancet Infect. Dis. 17:e101-e106. doi: 10.1016/S1473-3099(16)30518-7

Willenberg, B. J., and Seal, S. (2018). Passive Insect Surveillance Sensor Device. Available online at: https://patents.google.com/patent/WO2017027677A1/en? $\mathrm{q}=$ Passive\& $\mathrm{q}=$ Insect\&q=Surveillance\& $\mathrm{q}=$ Sensor\&q=Device\&oq=+Passive + Insect+Surveillance+Sensor+Device (accessed February 11, 2020).

Wolkowicz, R. (2018). Compositions and Cell-Based Methods for Monitoring the Activity of a Dengue Virus Protease. Available online at: https://patents.google. 
com/patent/US10006077B2/en?oq=US10006077B2 (accessed November 14, 2018).

Yaren, O., Alto, B. W., Gangodkar, P. V., Ranade, S. R., Patil, K. N., Bradley, K. M., et al. (2017). Point of sampling detection of Zika virus within a multiplexed kit capable of detecting dengue and chikungunya. BMC Infect. Dis. 17:293. doi: 10.1186/s12879-017-2382-0

Yen, C.-W., de Puig, H., Tam, J., Gómez-Márquez, J., Bosch, I., Hamad-Schifferli, K., et al. (2015). Multicolored silver nanoparticles for multiplexed disease diagnostics: distinguishing dengue, yellow fever, and ebola viruses. Lab Chip 15, 1638-1641. doi: 10.1039/C5LC00055F

Yrad, F. M., Castañares, J. M., and Alocilja, E. C. (2019). Visual detection of dengue-1 RNA using gold nanoparticle-based lateral flow biosensor. Diagnostics 9:74. doi: 10.3390/diagnostics9030074

Yujia, G, H., Wu, Y., and Chi, D. (2015). Green Synthesis Method of Gold Nanoparticles. Available online at: https://patents.google.com/patent/ $\mathrm{CN} 105057692 \mathrm{~A} / \mathrm{en}$ ?q=green\&q=synthesis\&q=nanoparticle\&oq $\$=+\$$ green $\$+$ \$synthesis\$+\$nanoparticle (accessed October 18, 2018).

Yusoh, S. N., Yaacob, K. A., and Alias, N. N. (2019). Trapezoidal SiNWs array fabricated by AFM-LAO for Dengue virus DNA oligomer detection. Mater. Res. Express 6:115005. doi: 10.1088/2053-1591/ab3571

Yuzon, Ma. K., Kim, J.-H., and Kim, S. (2019). A novel paper-plastic microfluidic hybrid chip integrated with a lateral flow immunoassay for dengue nonstructural protein 1 antigen detection. BioChip J. 13, 277-287. doi: 10.1007/s13206-019-3305-5

Zhang, B., Pinsky, B. A., Ananta, J. S., Zhao, S., Arulkumar, S., Wan, H., et al. (2017). Diagnosis of Zika virus infection on a nanotechnology platform. Nat. Med. 23, 548-550. doi: 10.1038/nm.4302

Zhang, Y., Chen, W., Jing, M., Liu, S., Feng, J., Wu, H., et al. (2018). Selfassembled mixed micelle loaded with natural pyrethrins as an intelligent nanoinsecticide with a novel temperature-responsive release mode. Chem. Eng. J. 361, 1381-1391. doi: 10.1016/j.cej.2018.10.132

Conflict of Interest: The authors declare that the research was conducted in the absence of any commercial or financial relationships that could be construed as a potential conflict of interest.

Copyright (C) 2020 Campos, de Oliveira, Abrantes, Rogério, Bueno, Miranda, Monteiro and Fraceto. This is an open-access article distributed under the terms of the Creative Commons Attribution License (CC BY). The use, distribution or reproduction in other forums is permitted, provided the original author(s) and the copyright owner(s) are credited and that the original publication in this journal is cited, in accordance with accepted academic practice. No use, distribution or reproduction is permitted which does not comply with these terms. 